Check for updates

Cite this: RSC Adv., 2017, 7, 27881

\title{
Absolute ion hydration enthalpies and the role of volume within hydration thermodynamics $\uparrow$
}

\author{
Catherine E. Housecroft (D) a and H. Donald Brooke Jenkins ${ }^{\star \mathrm{bc}}$ \\ This paper reports that various thermodynamic properties in aqueous media for certain individual ions and \\ for compounds are linear functions of the inverse cube root of the solid respective ionic and compound \\ solid state volumes, $V_{m}{ }^{-1 / 3}$. This is similar to the situation which has been fully exploited in solid state \\ thermodynamics and out of which volume-based thermodynamics, VBT, evolved. A short resume of \\ these various VBT applications is provided for the general reader and an improved lattice potential \\ energy equation emerges using the state of the art data presented in this paper.
}

Received 25th October 2016

Accepted 24th April 2017

DOI: $10.1039 / c 6 r a 25804 b$

rsc.li/rsc-advances

all that is needed is an EXCEL spreadsheet; the equations

\section{Introduction}

\section{Volume-based thermodynamics}

The primary aim of this paper is to investigate whether the inverse cube root of the formula unit volume, $V_{\mathrm{m}}{ }^{-1 / 3}$ of solid state species (as either single ions or as compounds) correlates with any of the thermodynamic functions associated with hydration (e.g. $\Delta_{\text {hyd }} H^{\mathrm{o}}$ or $\Delta_{\text {hyd }} G^{\mathrm{o}}$ or any of the more complex functions). There are several advantages if this were to be the case. Firstly it would bring the thermodynamic functions associated with hydration (and possibly also solvation functions in non-aqueous media) under the remit of Volume Based Thermodynamics (VBT). The availability of standard thermodynamic functions for non-aqueous media is rather sparse and such a link would enable expansion of the data in this area then possible. Secondly it would link hydration parameters with volume, $V_{\mathrm{m}}$, which is, in turn, intimately linked to and can be determined from crystal structure data which is routinely acquired for all new materials.

In 1999 Jenkins $^{1-7}$ and co-workers first introduced what they later termed VBT. The early ideas were based on work by Mallouk and Bartlett ${ }^{8}$ and were later extended by Jenkins and coworkers to a range of applications. ${ }^{9-28}$ The recognition of a link between the areas of crystallography (which supplies volume data) and hydration thermodynamics would provide considerable scope for the extension of hydration/solvation studies to more complex materials and applications. This would offer a number of advantages. The first is simplicity; VBT can be used easily by non-specialists in thermodynamics since

${ }^{a}$ Department of Chemistry, University of Basel, Spitalstrasse 51, CH-4056 Basel, Switzerland. E-mail: catherine.housecroft@unibas.ch

${ }^{b}$ Department of Chemistry, University of Warwick, Coventry CV4 7AL, West Midlands, UK. E-mail: h.d.b.jenkins@warwick.ac.uk

"“Fieldgate", 3, White Hill, Olney, MK46 5AY, Buckinghamshire, UK

$\dagger$ Electronic supplementary information (ESI) available: Tables S1-S5; Fig. S1-S2. See DOI: 10.1039/c6ra25804b involved have a simple format. Secondly, linking thermodynamics and crystallography gives access to volume data for modern solid state materials. If crystal structure data fail to provide volume information then it is possible to estimate formula unit volume, $V_{\mathrm{m}}$, using individual average volumes for each element in the formula unit, as derived from an analysis of the Cambridge Structural Database (CSD) by Hofmann. ${ }^{29}$ Examples are shown later. Using the cube root of the formula unit volume, $V_{\mathrm{m}}{ }^{1 / 3}$, means that the effect of any errors in the volume estimation are minimised by the need to extract the cube root.

Apart from one or two applications, the object of VBT so far has not been to obtain pristinely accurate thermodynamic values but rather to obtain reasonable approximations of such values which are good enough to show trends and which are accurate enough to guide synthetic work. Up until now no applications of VBT have been made for aqueous media but it is preparation for such an extension that is sought in this current work.

Specific applications of VBT to solving solid state chemistry problems include access to thermochemical studies in advance of synthesis. Examples have included a study ${ }^{9}$ of homopolyatomic cation species of $\mathrm{S}$ and $\mathrm{Se}\left(\right.$ e.g., $\mathrm{S}_{8}{ }^{2+}$ and $\left.\mathrm{Se}_{8}{ }^{2+}\right)$. Prior to chemical synthesis, VBT predicted the lattice stabilisation for the compound $\mathrm{S}_{8}\left(\mathrm{AsF}_{6}\right)_{2}$. Estimation of the formula unit volume, $V_{\mathrm{m}}$ permitted a rudimentary understanding of the energetics of this new area of chemistry. When used in tandem with the Thermodynamic Difference Rule (TDR), ${ }^{\mathbf{3 0}-35}$ VBT has made possible the provision of thermodynamic data for solvated materials. For example, it was possible to establish ${ }^{\mathbf{1 3}}$ that the solvated salt, $\mathrm{S}_{4}\left(\mathrm{AsF}_{6}\right)_{2} \cdot \mathrm{AsF}_{3}$ was more stable than its unsolvated counterpart, $\mathrm{S}_{4}\left(\mathrm{AsF}_{6}\right)_{2}$, as well being more stable than the likely decomposition products formed from $\mathrm{S}_{4}\left(\mathrm{AsF}_{6}\right)_{2} \cdot \mathrm{AsF}_{3}$. Similar questions concerning stability investigated using VBT can be found in our most sophisticated study to date, ${ }^{20}$ which used VBT coupled with TDR and enabled the study of species in liquid sulfur dioxide as solvent. VBT has been used quantitatively to 
arbitrate $^{\mathbf{1 0 - 1 2}}$ between two experimental measurements of $\Delta_{\mathrm{f}} H^{\mathrm{O}}\left(\mathrm{AsF}_{6}{ }^{-}, \mathrm{g}\right)$. A trend among some experimentalists, who believed that in order to synthesise new and more effective fluoride ion donors one needed to increase the size of the cation involved, was curbed by a VBT study. ${ }^{14,15}$ This was able to show that there was very little to be gained energetically in going beyond a critical cation size since the thermodynamics showed a plateau. In a more hypothetical vein, salts such as $\mathrm{N}_{5}{ }^{+} \mathrm{N}_{3}{ }^{-}$and $\mathrm{N}_{5}{ }^{+} \mathrm{N}_{5}{ }^{-}$were initially thought of as potential, environmentally clean, rocket propellants in advance of synthesis. VBT and $a b$ initio calculations ${ }^{17,18}$ showed that once synthesised they would be likely to decompose into $\mathrm{N}_{3}$ radicals and $\mathrm{N}_{2}$ gas and later bench experiments confirmed this fact. VBT, because of its versatility has made contributions to evolving technology, as for example in the case of electrochromic reactions which, inter alia, often depend on cation exchanges taking place in prussian blue. At the time of carrying this work "best formulations" were still being sought. VBT enabled us to unravel $^{19}$ some of the illunderstood ion exchange reactions accompanying the early electrochromic cycles. Such applications involve production of light sensitive glass windows for example. In addition, VBT has been used also to investigate the energetics of defence materials ${ }^{36}$ of current interest. We have found it possible to make thermodynamic predictions regarding the formation of such new materials. VBT ${ }^{37,38}$ has been used to predict the likely stability of certain alkali sulfoxalates and selenoxylates in the solid state. Since this publication ${ }^{37}$ appeared we were contacted by Makarov to report that he had already detected the $\mathrm{SO}_{2}{ }^{2-}$ moiety not in the solid state however but in aqueous solution. ${ }^{39-41}$

Coupled with TDR, VBT is able to examine reactions in nonaqueous media ${ }^{\mathbf{1 3 , 2 0}}$ Most recently TDR itself has been used to estimate thermodynamic data in the area of actinoid thermochemistry. Uranium salts are radioactive and therefore need thermochemical measurements to be made in specially equipped laboratories. Their hydrolysis reactions can often create the need to make challenging thermochemical adjustments ${ }^{35}$ which means that TDR has a useful function in avoiding such requirements. Questions of academic interest have also been explored using VBT. While $\left[\mathrm{P}\left(\mathrm{C}_{6} \mathrm{H}_{5}\right)_{4}\right]^{+} \mathrm{N}_{3}{ }^{-}$and $\left[\mathrm{As}\left(\mathrm{C}_{6} \mathrm{H}_{5}\right)_{4}\right]^{+} \mathrm{N}_{3}{ }^{-}$ are known to exist as ionic salts while later members of the group: $\left[\mathrm{Sb}\left(\mathrm{C}_{6} \mathrm{H}_{5}\right)_{4}\right]^{+} \mathrm{N}_{3}{ }^{-}$and $\left[\mathrm{Bi}\left(\mathrm{C}_{6} \mathrm{H}_{5}\right)_{4}\right]^{+} \mathrm{N}_{3}{ }^{-}$are covalent solids. VBT was used to explain ${ }^{26}$ why this should be.

The above applications are but a few to capture the interest of the general reader. Many other applications possess novel features ${ }^{\mathbf{4} 23,45}$ and have shown themselves capable of unravelling quite complex thermochemistry. ${ }^{\text {21,23,43-45}}$ Further applications continue to emerge, ${ }^{42}$ and a recent review of the main features of VBT has appeared. ${ }^{7}$

More recently, ionic strength, $I$ and formula unit volume, $V_{\mathrm{m}}$ - essential components of VBT - have found application as measures of the enhanced stability brought about to Zintl structures as part of a recently emerging interpretation and new realm of crystallography in which the Zintl-Klemm ${ }^{\mathbf{4 6}-49}$ concept has been revived and extended and which now, once correctly applied, enables the prediction and rationalisation of crystal structures. ${ }^{\mathbf{4 8 , 4 9}}$ This area of crystallography is destined to yield new and exciting ideas in the future. ${ }^{50}$
The above examples illustrate some of the problems it has been possible to tackle once the connection between crystallography and thermodynamics via volume had been established. If a link can similarly be established between $V_{\mathrm{m}}{ }^{-1 / 3}$ and hydration thermodynamics then, by analogy with these solid state developments, this should promote new developments in a number of areas of hydration and solvation chemistry. This paper represents the very beginnings of this process.

\section{Volume estimation}

In order to estimate ion volumes, $V_{\mathrm{m}}$, there are four immediate sources one can use which separate into two categories. Three relate to data evolving from crystal structure determinations and the other (which is often much less appropriate for correlation with hydration thermodynamics) derives volume from radii, $r$, $\left(4 \pi r^{3}\right)$ and therefore the assumption that the ion is spherical. Since the majority of ions are patently non-spherical it is better to use volume data from crystal structure sources $\left(V_{\text {cell }} / Z\right)$. Such volume data is to be found in our seminal publication ${ }^{\mathbf{1}}$ providing estimates by dividing up space and apportioning it without invoking assumptions about sphericity. Another source of volume data can come directly from density, $\rho$, measurements: ${ }^{3}$

$$
V_{\text {cell }} / \mathrm{nm}^{3}=1.66 \times 10^{-3} Z\left(M_{\mathrm{m}} / \mathrm{g}\right) /\left(\rho / \mathrm{g} \mathrm{cm}^{-3}\right)
$$

where $M_{\mathrm{m}}$ is the chemical formula mass of the material and $Z$ is the number of formula units per cell . Finally Hofmann, ${ }^{29}$ persuing an analysis of the Cambridge Structure Database (CSD) has produced average atomic volumes which can then be used in conjunction with chemical formulae to estimate volumes of materials or of ions. This latter approach is, however, not entirely satisfactory.

\section{Revisions of hydration thermodynamics}

In 2006 Kelly, Cramer and Truhlar ${ }^{51}$ were able to confirm the absolute aqueous solvation free energy of the proton, $\Delta_{\mathrm{hyd}^{-}}$ $G^{\mathrm{o}}\left(\mathrm{H}^{+}, \mathrm{g}\right)$ as $-1112.5 \mathrm{~kJ} \mathrm{~mol}^{-1}$ in close agreement to the value $-1104.5 \mathrm{~kJ} \mathrm{~mol}^{-1}$ obtained by Tissendier et al. ${ }^{52}$ in 1998 using the cluster-pair-based approximation and thermodynamic properties of ion-water clusters. Tawa et al. also made a similar theoretical determination. ${ }^{68}$ They showed that historical data were mostly inconsistent with the cluster data. As further confirmation, their value is also consistent with the absolute free energy of the $\mathrm{OH}^{-}$ion as obtained via Monte Carlo calculations. ${ }^{69,70}$ The corresponding absolute aqueous solvation enthalpy of the proton, $\Delta_{\mathrm{hyd}} H^{\mathrm{o}}\left(\mathrm{H}^{+}, \mathrm{g}\right)$, as determined by these latter workers was $-1150.1 \mathrm{~kJ} \mathrm{~mol}^{-1}$ which in turn agreed with the value $-1152.6 \mathrm{~kJ} \mathrm{~mol}^{-1}$ recorded by Coe. ${ }^{53}$ In the case of $\Delta_{\text {hyd }} H^{\mathrm{O}}\left(\mathrm{H}^{+}, \mathrm{g}\right)$ traditional values had previously spanned a much higher range $\left(-1085>\Delta_{\text {hyd }} H^{\mathrm{o}}\left(\mathrm{H}^{+}, \mathrm{g}\right) / \mathrm{kJ} \mathrm{mol}^{-1}>-1125\right)$ and their derivation had almost always needed to rely on the use of an extra-thermodynamic assumption. The cluster-derived data does not, however, need to rely on such an assumption and Tissendier's data are currently the most commonly accepted values (see also Camaioni and Schwerdtfeger ${ }^{62}$ ). The determinations of single ion hydration values made before 1998 can 
differ by, on average $50 \mathrm{~kJ} \mathrm{~mol}^{-1}$, from the more recent values. This has naturally led to the necessity for quantitative reassessment of traditional thermodynamic values in hydration thermochemistry.

\section{Results and discussion}

\section{The Born equation and correlation of hydration data with $V^{-1 / 3}$}

The first question is: why might one expect hydration thermodynamic functions to follow the pattern of VBT for solids and be functions of $V^{-1 / 3}$ ? The first clue comes from the fact that the Born $^{55}$ equation (now almost a century old) for the Gibbs free energy of transfer of a gaseous ion of charge $z$ and radius, $r$ into a medium whose relative permittivity (or dielectric constant) is $\varepsilon_{\mathrm{r}}(=78.7$ for water $)$ is given by:

$$
\Delta G_{\text {hyd }}^{\mathrm{o}}\left(\text { ion, g) } / \mathrm{J} \mathrm{mol}{ }^{-1}=-10^{-3} L z^{2} e^{2}\left[1-\left(1 / \varepsilon_{\mathrm{r}}\right)\right] / 8 \pi \varepsilon_{\mathrm{o}} r\right.
$$

where $L$ is the Avogadro number $\left(6.022 \times 10^{23} \mathrm{~mol}^{-1}\right), e$ is the charge on the electron $\left(1.602 \times 10^{-19} \mathrm{C}\right) ; z$ for monatomic cations is +1 and for anions $-1 ; \varepsilon_{0}$ is the relative permittivity of a vacuum $\left(8.854 \times 10^{-3} \mathrm{~F} \mathrm{~nm}^{-1}\right)$ and $r$ is the radius of the ion (in $\mathrm{m}$ ). In practice this expression gives unsatisfactory results since the relative permittivity of bulk water of $\mathbf{7 8 . 7}$ is not appropriate to use close to an ion so we can therefore anticipate that this expression can, at best, only be relied on to show the functional dependence of $\Delta G_{\text {hyd }}^{\mathrm{o}}($ ion,g) whilst failing to give the precise values of the coefficients of the dependence (see later however). We proceed by relating the radius of the ion, $r$ to volume, $V_{\mathrm{m}}$, of the ion as follows:

$$
V_{\mathrm{m}} / \mathrm{nm}^{3}=4 \pi r^{3} / 3
$$

where $r$ is in $\mathrm{nm}$, so that we are restricting the equation generated to apply only to spherical ions:

$$
(r / \mathrm{nm})^{3}=3 V_{\mathrm{m}} / 4 \pi
$$

and

$$
r / \mathrm{nm}=(3)^{1 / 3} V_{\mathrm{m}}^{1 / 3} /(4 \pi)^{1 / 3}=0.6203 V_{\mathrm{m}}^{1 / 3}
$$

where $V_{\mathrm{m}}{ }^{1 / 3}$ is in $\mathrm{nm}^{-1}$. Substituting for $r / \mathrm{nm}$ in eqn (2) leads to the expression:

$$
\begin{aligned}
& \Delta G_{\mathrm{hyd}}^{\mathrm{o}}(\text { ion }, \mathrm{g}) / \mathrm{kJ} \mathrm{mol}^{-1}= \\
& -10^{-3} L z^{2} e^{2}\left[1-\left(1 / \varepsilon_{\mathrm{r}}\right)\right] /\left\{8 \pi \varepsilon_{\mathrm{o}}[0.6203] V_{\mathrm{m}}{ }^{1 / 3}\right\}
\end{aligned}
$$

Inserting the constants in eqn (6) for a cation having charge $z=1$ gives:
We should note also that since $z^{2}=1$ for both cation and anion, eqn (7) represents the approximate form of the relationship hoped for to apply to thermodynamic properties in solution and one which is directly in keeping with VBT namely that:

$$
\Delta G_{\mathrm{hyd}}^{\mathrm{o}}(\mathrm{ion}, \mathrm{g}) / \mathrm{kJ} \mathrm{mol}^{-1} \text { is proportional to } f\left(V_{\mathrm{m}}{ }^{-1 / 3}\right)
$$

\section{Assembling of state-of-the-art thermodynamic data}

In the ESI to this paper Table S1 $\uparrow$ lists $\Delta_{\mathrm{f}} H^{\mathrm{o}}(\mathrm{ion}, \mathrm{g}) / \mathrm{kJ} \mathrm{mol}^{-1}$ and $\Delta_{\mathrm{f}} G^{\mathrm{O}}$ (ion,g) $/ \mathrm{kJ} \mathrm{mol}^{-1}$ data $^{54}$ for the proton, alkali metal and halide ions according to the electron convention using Boltzmann statistics. Further state-of-the-art thermodynamic values (in $\mathrm{kJ} \mathrm{mol}^{-1}$ ) are to be found in Table $\mathrm{S} 2 \uparrow \Delta_{\mathrm{f}} H^{\mathrm{O}}\left(\mathbf{M}^{+}\right.$,aq) and $\Delta_{\mathrm{f}} H^{\mathrm{o}}\left(\mathrm{X}^{-}, \mathrm{aq}\right)$; in Table S3 $\uparrow \Delta_{\mathrm{f}} H^{\mathrm{o}}(\mathrm{MX}, \mathrm{s})$; in Table $\mathrm{S} 4 \uparrow \Delta_{\mathrm{f}} G^{\mathrm{O}}(\mathrm{MX}, \mathrm{s})$; in Table S5 $\dagger \Delta_{\text {latt }} H^{\mathrm{o}}(\mathrm{MX}, \mathrm{s})$; and in Table S6 $\dagger U_{\mathrm{POT}}(\mathrm{MX})$ and in Table $\mathrm{S} 7 \dagger \Delta_{\text {soln }} H^{\mathrm{O}}(\mathrm{MX}, \mathrm{S})$. Table $\mathrm{S} 8 \dagger$ lists values of $V_{\mathrm{m}}(\mathrm{MX})^{-1 / 3}$ in $\mathrm{nm}^{-1}$ for the alkali halides.

\section{VBT as applied to hydration studies}

Alkali metal ion plots versus $V_{\mathbf{m}}{ }^{-1 / 3}$. Table 1 gives the values of $\Delta_{\text {hyd }} H^{\mathrm{O}}\left(\mathrm{M}^{+}, \mathrm{g}\right)$ and $\Delta_{\mathrm{hyd}} G^{\mathrm{O}}\left(\mathrm{M}^{+}, \mathrm{g}\right)$ for proton and the alkali metal ions and the appropriate values of $V_{\mathrm{m}}{ }^{-1 / 3}$ for the spherical ions in question and Fig. 1 and 2 give the plots of $\Delta_{\text {hyd }} H^{\mathrm{o}}\left(\mathrm{M}^{+}, \mathrm{g}\right) / \mathrm{kJ} \mathrm{mol}^{-1}$ versus $V_{\mathrm{m}}{ }^{-1 / 3} / \mathrm{nm}^{-1}$ and $\Delta_{\mathrm{hyd}} G^{\mathrm{O}}\left(\mathrm{M}^{+}, \mathrm{g}\right) / \mathrm{k} \mathrm{mol}^{-1}$ versus $V_{\mathrm{m}}{ }^{-1 / 3} / \mathrm{nm}^{-1}$ respectively from which we see rectilinear relationships emerging with correlation coefficients of $R^{2}=0.9999$ and $R^{2}=0.9996-$ almost perfect straight lines - the analytical forms of which are:

$$
\begin{gathered}
\Delta_{\mathrm{hyd}} H^{\mathrm{o}}\left(\mathrm{M}^{+}, \mathrm{g}\right)=-48.2 V_{\mathrm{m}}{ }^{-1 / 3}-154.6\left(N=6 ; R^{2}=0.9999\right) \\
\Delta_{\mathrm{hyd}} G^{\mathrm{o}}\left(\mathrm{M}^{+}, \mathrm{g}\right)=-47.1 V_{\mathrm{m}}{ }^{-1 / 3}-128.5\left(N=6 ; R^{2}=0.9996\right)
\end{gathered}
$$

These relationships, in respect of their linear dependence on $V_{\mathrm{m}}{ }^{-1 / 3}$ are similar to those found for thermodynamic functions in VBT in the solid state.

The hydration data given in Table 1 is currently the most up to data (2017) and is obtained by using the thermochemical cycle shown in Fig. 3, from which we see that:

$$
\begin{aligned}
\Delta_{\mathrm{hyd}} H^{\mathrm{o}}\left(\mathrm{M}^{+}, \mathrm{g}\right)+\Delta_{\mathrm{hyd}} H^{\mathrm{o}}\left(\mathrm{X}^{-}, \mathrm{g}\right) \\
=\Delta_{\mathrm{f}} H^{\mathrm{o}}\left(\mathrm{M}^{+}, \mathrm{aq}\right)+\Delta_{\mathrm{f}} H^{\mathrm{o}}\left(\mathrm{X}^{-}, \mathrm{aq}\right)-\Delta_{\mathrm{f}} H^{\mathrm{o}}\left(\mathrm{M}^{+}, \mathrm{g}\right) \\
\quad-\Delta_{\mathrm{f}} H^{\mathrm{o}}\left(\mathrm{X}^{-}, \mathrm{g}\right)
\end{aligned}
$$

The NIST-JANAF tables ${ }^{54}$ give the gaseous ion formation data (Table S1†) and using conventional solvated ion

$$
\begin{aligned}
\Delta G_{\text {hyd }}^{\mathrm{o}}(\text { ion, g }) / \mathrm{kJ} \mathrm{mol}^{-1} & =\frac{-10^{-3}\left[\left(6.022 \times 10^{23} \mathrm{~mol}^{-1}\right) \times\left(1.602 \times 10^{-19}\right)^{2}\right] C^{2} \times[1-(1 / 78.7)] z^{2}}{\left[8 \times 3.142 \times\left(8.854 \times 10^{-12} \mathrm{~F} \mathrm{~m}^{-1}\right)\right] \times\left[0.6203 \times 10^{-9} \mathrm{~m}\right] V_{\mathrm{m}}{ }^{1 / 3}} \\
& =-\left[15.257 \times 10^{-18}\right] /\left[138.05 \times 10^{-21}\right] V_{\mathrm{m}}{ }^{1 / 3} \\
& =-110.52 V_{\mathrm{m}}{ }^{-1 / 3}
\end{aligned}
$$


Table 1 Values of absolute single-ion hydration enthalpies and free energies: $\Delta_{\text {hyd }} H^{\circ}\left(M^{+}, g\right)$ and $\Delta_{\text {hyd }} G^{\circ}\left(M^{+}, g\right)$ in kJ mol ${ }^{-1}$ for alkali metal ions and proton together with associated radii, $r$ (in $\mathrm{nm}$ ) volume, $V_{\mathrm{m}}\left(=4 \pi r^{3} / 3\right)$ (in $\left.\mathrm{nm}^{3}\right)$ and $V_{\mathrm{m}}{ }^{-1 / 3}$ in $\mathrm{nm}$

\begin{tabular}{|c|c|c|c|c|c|}
\hline Cation & Radius, $r / \mathrm{nm}$ & Volume, $V_{\mathrm{m}} / \mathrm{nm}^{3}$ & $V_{\mathrm{m}}^{-1 / 3} / \mathrm{nm}^{-1}$ & $\Delta_{\text {hyd }} H^{\mathrm{o}}\left(\mathrm{M}^{+}, \mathrm{g}\right) / \mathrm{kJ} \mathrm{mol}^{-1}$ & $\Delta_{\text {hyd }} G^{\mathrm{O}}\left(\mathrm{M}^{+}, \mathrm{g}\right) / \mathrm{kJ} \mathrm{mol}^{-1}$ \\
\hline $\mathrm{H}^{+}$ & $0.030^{a}$ & $0.000115^{e}$ & 20.67558 & -1150.1 & -1104.5 \\
\hline $\mathrm{Li}^{+}$ & $0.071^{b}$ & $0.0015^{e}$ & 8.736159 & -578.1 & -529.3 \\
\hline $\mathrm{K}^{+}$ & $0.133^{c, d}$ & $0.00986^{c}$ & 4.663454 & -380.3 & -351.8 \\
\hline $\mathrm{Rb}^{+}$ & $0.149^{c, d}$ & $0.01386^{c}$ & 4.163056 & -355.2 & -329.3 \\
\hline $\mathrm{Cs}^{+}$ & $0.165^{c, d}$ & $0.01882^{c}$ & 3.759471 & -330.6 & -306.4 \\
\hline
\end{tabular}

${ }^{a}$ Proton radius taken from Marcus Table 3 ref. 56. ${ }^{b} \mathrm{Li}^{+}$radius taken from Vieillard ${ }^{57}$ as cited by Marcus. ${ }^{56}{ }^{c}$ Taken from Table 4 , ref. 1. ${ }^{d}$ Goldschmidt radius. ${ }^{58}{ }^{e}$ Calculated from radius (column 1) from Marcus ${ }^{56}$ Table 3, charge ignored. Ions are spherical so calculation for radius, $r$, as $4 \pi r^{3} / 3$ is acceptable here.

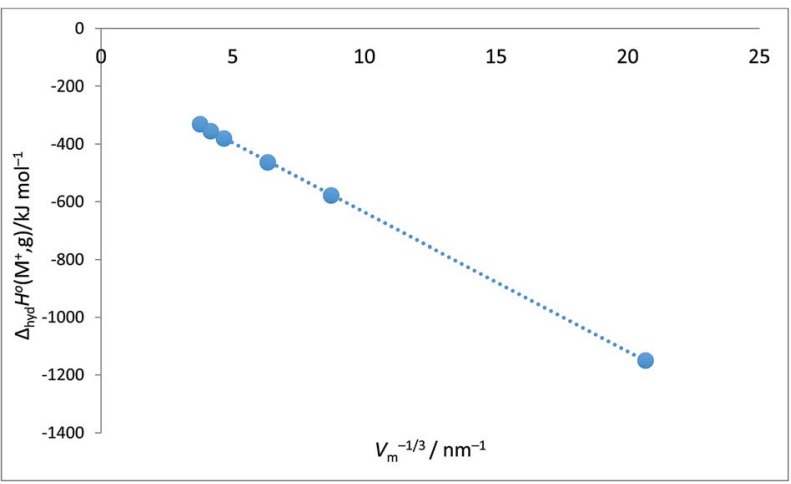

Fig. 1 Plot of $\Delta_{\text {hyd }} H^{\circ}\left(M^{+}, \mathrm{g}\right) / \mathrm{kJ} \mathrm{mol}^{-1}$ as ordinate versus $V_{\mathrm{m}}{ }^{-1 / 3} / \mathrm{nm}^{-1}$ for proton and alkali metal ions as listed in Table 2. $\Delta_{\text {hyd }} H^{\circ}\left(M^{+}, \mathrm{g}\right) / \mathrm{kJ}$ $\mathrm{mol}^{-1}=-48.2 V_{\mathrm{m}}^{-1 / 3}-154.6\left(\mathrm{~N}=6, R^{2}=0.9999\right)$.

thermodynamics we have the $\Delta_{\mathrm{f}} H^{\mathrm{o}}\left(\mathrm{M}^{+}\right.$, aq $)$and $\Delta_{\mathrm{f}} H^{\mathrm{o}}\left(\mathrm{X}^{-}\right.$,aq $)$ values (Table S2 $\dagger$ ) since:

$\left[\Delta_{\mathrm{f}} H^{\mathrm{o}}\left(\mathrm{M}^{+}, \mathrm{aq}\right)+\Delta_{\mathrm{f}} H^{\mathrm{o}}\left(\mathrm{X}^{-}, \mathrm{aq}\right)\right]=\Delta_{\mathrm{f}} H^{\mathrm{o}}(\mathrm{MX}, \mathrm{s})+\Delta_{\mathrm{soln}} H^{\mathrm{o}}(\mathrm{MX}, \mathrm{s})$

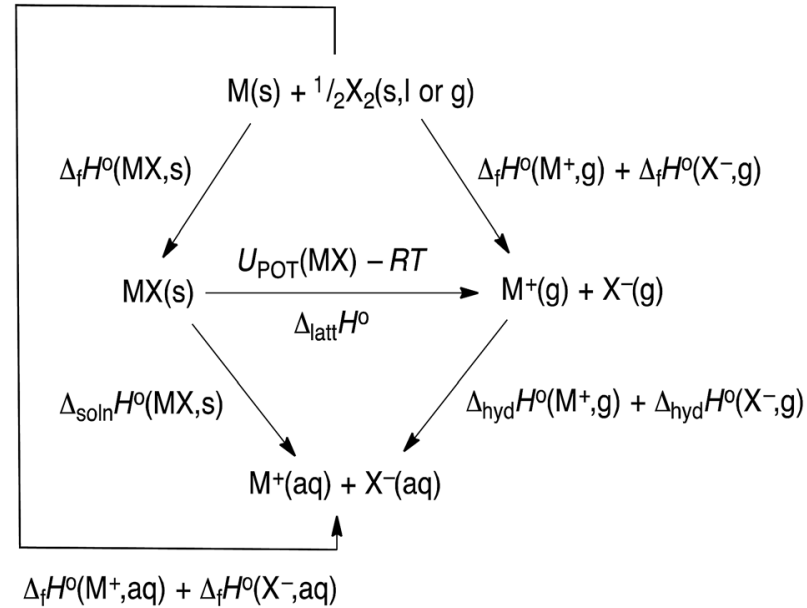

Fig. 3 Thermochemical cycle.

\section{Lattice potential energy equation for MX (1:1) salts using} latest data

Using data ${ }^{54,63-65}$ from Tables $\mathrm{S} 1$ and $\mathrm{S} 3 \uparrow$ and the cycle in Fig. 3 we can obtain the lattice potential energy, $U_{\mathrm{POT}}(\mathrm{MX})$ (Table $\mathrm{S} 6 \dagger$ ) using the equation:

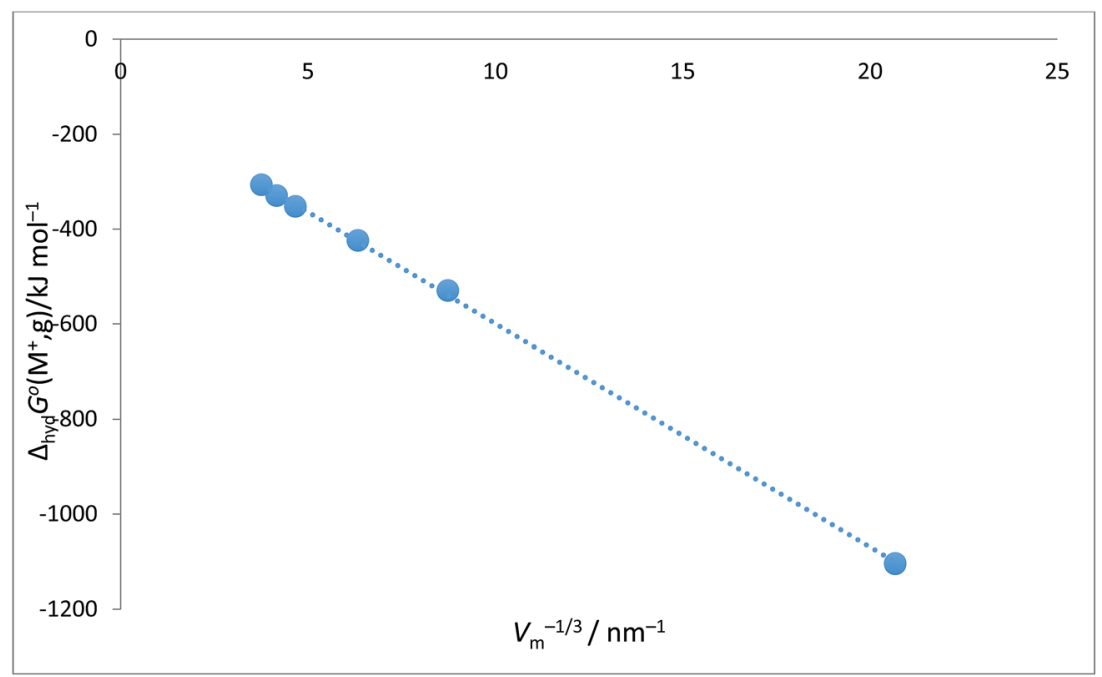

Fig. 2 Plot of $\Delta_{\text {hyd }} G^{\circ}\left(M^{+}, \mathrm{g}\right) / \mathrm{kJ} \mathrm{mol}^{-1}$ as ordinate versus $V_{\mathrm{m}}{ }^{-1 / 3} / \mathrm{nm}^{-1}$ for proton and alkali metal ions as listed in Table 2 . $\Delta_{\text {hyd }} G^{\circ}\left(M^{+}, \mathrm{g}\right) / \mathrm{kJ} \mathrm{mol}^{-1}$ $=-47.1 V_{\mathrm{m}}^{-1 / 3}-128.5\left(N=6, R^{2}=0.9996\right)$. 


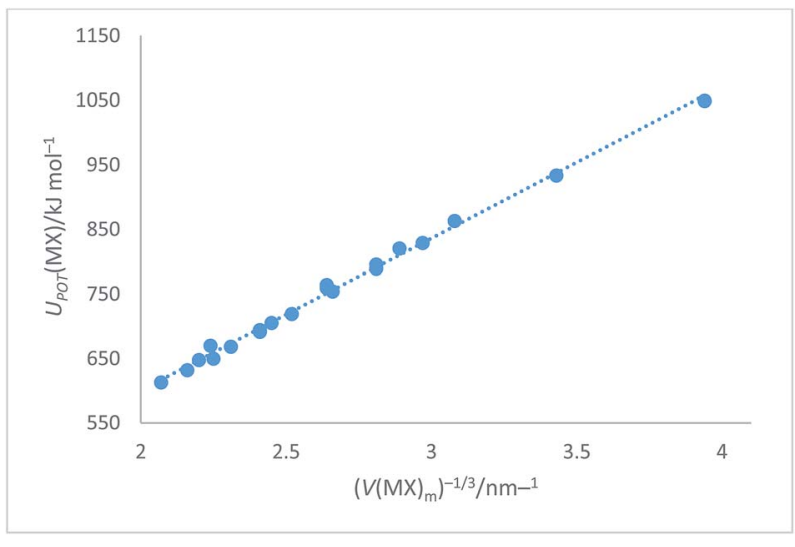

Fig. 4 Plot of $U_{\mathrm{POT}}(\mathrm{MX}) / \mathrm{kJ} \mathrm{mol}^{-1}$ as ordinate versus $V(M X)_{\mathrm{m}}^{-1 / 3}$ as abscissa. The plot takes the analytical form: $U_{\mathrm{POT}}(\mathrm{MX}) / \mathrm{kJ} \mathrm{mol}^{-1}=$ 2/[117.8 $\left.\left(V(M X)_{m}\right)^{-1 / 3}+64.5\right]$ with correlation coefficient $R^{2}=0.996$, $N=20$.

$U_{\text {POT }}(\mathrm{MX})=\Delta_{\mathrm{f}} H^{\mathrm{o}}\left(\mathrm{M}^{+}, \mathrm{g}\right)+\Delta_{\mathrm{f}} H^{\mathrm{o}}\left(\mathrm{X}^{-}, \mathrm{g}\right)-\Delta_{\mathrm{f}} H^{\mathrm{o}}(\mathrm{MX}, \mathrm{s})+R T$

which when plotted versus $V(\mathrm{MX})^{-1 / 3}$ (Table S8 $\dagger$ ) as shown in Fig. 4 , leads to the equations:

$$
\begin{aligned}
& U_{\mathrm{POT}}(\mathrm{MX}) / \mathrm{kJ} \mathrm{mol}^{-1}=\left|z_{+} \| z_{-}\right| \nu\left(\alpha / V^{-1 / 3}+\beta\right) \\
& =\sum n_{k} \mathrm{z}_{k}^{2}\left(\alpha / V^{-1 / 3}+\beta\right)=2 I\left(117.8 V^{-1 / 3}+64.5\right)\left(R^{2}=0.996\right)
\end{aligned}
$$

where $\nu$ is the number of ions in the formula unit $(=2), I$ is the ionic strength of the lattice $(=1)$ defined for $(1: 1)$ salts by:

$$
I=1 / 2 \sum n_{i} z_{i}^{2}=\frac{1}{2}\left[(1)(+1)^{2}+(1)(-1)^{2}\right]=1
$$

where $n_{i}$ is the number of ions in the lattice with charge $z_{i}$ and the summation is over the whole lattice.

In the cycle the lattice enthalpy, $\Delta_{\text {latt }} H^{\mathrm{o}}$ (MX,s) (Table S5 $†$ ) can replace $U_{\mathrm{POT}}(\mathrm{MX})-R T$.

Eqn (14) represents an improved rectilinear fit, (Fig. 4), in the sense that $R^{2}=0.996$ when compared to $R^{2}=0.94$ previously ${ }^{1}$ used for the alkali halides in VBT. This update refers, of course, to the solid state but, being a significant improvement on the main VBT equation, it is important to record this update in this paper. Section S3 of the ESI $\dagger$ lists other enthalpy and free energy relationships which can be inferred from the cycle (Fig. 3).

Prediction of hydration data. Eqn (9) and (10) can be used to regenerate the data used to create them. The results (shown in Table 2) are, in both cases, highly satisfactory.
Table 2 (columns 3 and 6) shows the original datasets (taken from Table 1, in columns 5 and 6) and alongside them the regenerated data (in columns 4 and 7) and the percentage differences (in columns 5 and 8) from which can be seen that eqn (9) predicts $\Delta_{\text {hyd }} H^{\circ}\left(\mathrm{M}^{+}, \mathrm{g}\right)$ values at least to within $5.3 \mathrm{~kJ}$ $\mathrm{mol}^{-1}$ (or to within $1.6 \%$ ) whilst eqn (10) predicts $\Delta_{\text {hyd }} G^{\mathrm{O}}\left(\mathrm{M}^{+}, \mathrm{g}\right.$ ) values to at least to within $4.9 \mathrm{~kJ} \mathrm{~mol}^{-1}$ (or to within $1.5 \%$ ). This level of certainty gives confidence that values predicted for other $\mathrm{M}^{+}$ions, using data for the inverse cube root of their volumes, $V_{\mathrm{m}}{ }^{-1 / 3}$ should be reasonably close to their true values.

Some of the ions in Table 3 are clearly spherical $\left(\mathrm{Cu}^{+}, \mathrm{Ag}^{+}\right.$, $\mathrm{Au}^{+}, \mathrm{Ga}^{+}, \mathrm{In}^{+}, \mathrm{Tl}^{+}$) whereas the remainder are not. For the ions that are spherical we can calculate the volume using their radius (column 2) as a basis. For those that are non-spherical the volumes used are best sourced from crystallography ${ }^{1}$ (and not from radii). In Table 3 we compare the volumes of two of the ions $\left(\mathrm{Me}_{4} \mathrm{~N}^{+}\right.$and $\left.\mathrm{Et}_{4} \mathrm{~N}^{+}\right)$sourced from radii and also from crystallography. Comparing $\Delta_{\text {hyd }} H^{\mathrm{o}}\left(\mathrm{R}_{4} \mathrm{~N}^{+}, \mathrm{g}\right)$ and $\Delta_{\text {hyd }} G^{\mathrm{o}}\left(\mathrm{R}_{4} \mathrm{~N}^{+}, \mathrm{g}\right)$, the values predicted for $\Delta_{\text {hyd }} H^{\mathrm{O}}\left(\mathrm{Me}_{4} \mathrm{~N}^{+}, \mathrm{g}\right)$ for $\mathrm{Me}_{4} \mathrm{~N}^{+}$differ by only $7.1 \mathrm{~kJ} \mathrm{~mol}^{-1}$ and in the case of $\mathrm{Et}_{4} \mathrm{~N}^{+}, \Delta_{\text {hyd }} H^{\mathrm{O}}\left(\mathrm{Et}_{4} \mathrm{~N}^{+}, \mathrm{g}\right)$ differs by $6.2 \mathrm{~kJ} \mathrm{~mol}^{-1}$. For $\Delta_{\text {hyd }} G^{\mathrm{O}}\left(\mathrm{R}_{4} \mathrm{~N}^{+}, \mathrm{g}\right)$ the situation is similar, Table 3 shows a difference in $\Delta_{\text {hyd }} G^{\circ}\left(\mathrm{Me}_{4} \mathrm{~N}^{+}, \mathrm{g}\right)$ of some $6.9 \mathrm{~kJ} \mathrm{~mol}^{-1}$ whilst for $\mathrm{Et}_{4} \mathrm{~N}^{+}$it reduces to $6.0 \mathrm{~kJ} \mathrm{~mol}^{-1}$. Although these two cases are reassuring they do not necessarily reflect the situation for other ions.

Halide ion plots versus $V_{\mathrm{m}}{ }^{-1 / 3}$. Fig. 5 and 6 give the plots of $\Delta_{\text {hyd }} H^{\mathrm{o}}\left(\mathrm{X}^{-}, \mathrm{g}\right) / \mathrm{kJ} \mathrm{mol}^{-1}$ versus $V_{\mathrm{m}}^{-1 / 3} / \mathrm{nm}^{-1}$ and $\Delta_{\mathrm{hyd}} G^{\mathrm{o}}\left(\mathrm{X}^{-}, \mathrm{g}\right) / \mathrm{kJ}$ $\mathrm{mol}^{-1}$ versus $V_{\mathrm{m}}{ }^{-1 / 3} / \mathrm{nm}^{-1}$ respectively using the data displayed in Table 4. Here we see rectilinear relationships emerging with correlation coefficients indicative of them being very close to perfect straight lines:

$$
\Delta_{\mathrm{hyd}} H^{\mathrm{o}}\left(\mathrm{X}^{-}, \mathrm{g}\right)=-214.71 V_{\mathrm{m}}{ }^{-1 / 3}+271.96\left(N=4 ; R^{2}=0.9992\right)
$$

$$
\Delta_{\mathrm{hyd}} G^{\mathrm{o}}\left(\mathrm{X}^{-}, \mathrm{g}\right)=-185.22 V_{\mathrm{m}}^{-1 / 3}+205.72\left(N=4 ; R^{2}=0.9985\right)
$$

Eqn (7), (10) and (17), when compared, differ considerably in respect of the magnitude of their gradients, eqn (17) being considerably lower (more negative at $-185 \mathrm{~kJ} \mathrm{~mol}^{-1} \mathrm{~nm}$ ) than that of eqn (10) (at $-47 \mathrm{~kJ} \mathrm{~mol}^{-1} \mathrm{~nm}$ ). However both are negative and have correlation coefficients which are virtually unity. If one averages the gradients of eqn (10) for the alkali metal cations and eqn (17) for the halide anions their average

Table 2 Test of the extent to which eqn (9) and (10) are capable of reproducing the absolute hydration data used to determine them

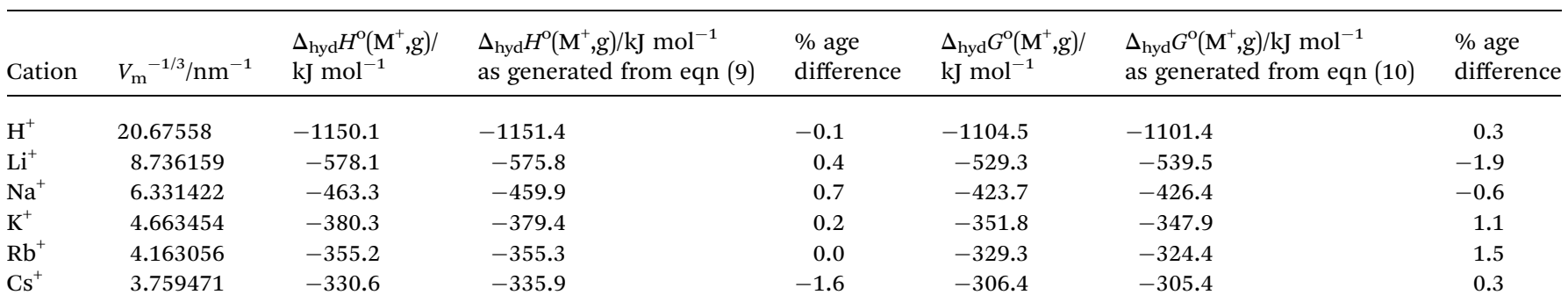


Table 3 Prediction of values of absolute single-ion hydration enthalpies and free energies: $\Delta_{\text {hyd }} H^{\circ}\left(M^{+}, g\right)$ and $\Delta_{\text {hyd }} G^{\circ}\left(M^{+}, g\right)\left(\right.$ in $\mathrm{kJ}$ mol $\left.{ }^{-1}\right)$ for a series of spherical and non-spherical singly charged cations

\begin{tabular}{|c|c|c|c|c|c|c|c|}
\hline Cation & Radius, $r / \mathrm{nm}$ & $V_{\mathrm{m}} / \mathrm{nm}^{3}$ & $V_{\mathrm{m}}^{-1 / 3} / \mathrm{nm}^{-1}$ & $\begin{array}{l}\text { Estimated } \\
\Delta_{\text {hyd }} H^{\mathrm{O}}\left(\mathrm{M}^{+}, \mathrm{g}\right) / \mathrm{kJ} \mathrm{mol}^{-1} \\
\text { from eqn }(9)\end{array}$ & $\begin{array}{l}\text { Values of } \\
\Delta_{\text {hyd }} H^{\mathrm{O}}\left(\mathrm{M}^{+}, \mathrm{g}\right) / \mathrm{kJ} \mathrm{mol}^{-1} \\
\text { from other work }\end{array}$ & $\begin{array}{l}\text { Estimated } \\
\Delta_{\text {hyd }} G^{\mathrm{O}}\left(\mathrm{M}^{+}, \mathrm{g}\right) \mathrm{kJ} \mathrm{mol}^{-1} \\
\text { from eqn }(10)\end{array}$ & $\begin{array}{l}\text { Values of } \\
\Delta_{\text {hyd }} G^{\mathrm{O}}\left(\mathrm{M}^{+}, \mathrm{g}\right) / \mathrm{kJ} \mathrm{mol}^{-1} \\
\text { from other work }\end{array}$ \\
\hline $\mathrm{Ag}^{+}$ & $0.113^{a}$ & 0.0060 & 5.489 & -419.2 & - & -386.8 & $-496.6^{g}$ \\
\hline $\mathrm{Au}^{+}$ & $0.137^{a}$ & 0.0108 & 4.527 & -372.9 & - & -341.5 & - \\
\hline $\mathrm{Ga}^{+}$ & $0.113^{b}$ & 0.0060 & 5.489 & -419.2 & - & -386.8 & - \\
\hline $\mathrm{NH}_{4}^{+}$ & & & & & & & $-349.8^{h}$ \\
\hline \multirow{4}{*}{$\mathrm{CH}_{3} \mathrm{NH}_{3}^{+}$} & & $0.021^{c}$ & 3.625 & -329.4 & - & -299.0 & $\begin{array}{l}-356.5^{i} \\
-355.2^{f}\end{array}$ \\
\hline & & & 0.025 & -329.4 & - & -299.0 & $\begin{array}{l}-355.2^{2} \\
-313.0^{h}\end{array}$ \\
\hline & & & & & & & $-320.1^{i}$ \\
\hline & & $0.051^{c}$ & 2.697 & -284.6 & - & -255.4 & $-319.7^{g}$ \\
\hline $\mathrm{Pr}_{4} \mathrm{~N}^{+}$ & $0.379^{d}$ & 0.2952 & 1.636 & -233.5 & - & -205.4 & - \\
\hline $\mathrm{Bu}_{4} \mathrm{~N}^{+}$ & $0.413^{d}$ & 0.0736 & 1.502 & -227.0 & - & -199.1 & - \\
\hline
\end{tabular}

${ }^{a}$ Goldschmidt radius. ${ }^{58} b$ Pauling radius. ${ }^{59} c$ Taken from Table 6 ref. 1 from crystal structure data. ${ }^{d}$ Taken from ref. 60 and also selected value of radius given in Table 3 ref. $56 .{ }^{e}$ In the case of $\mathrm{Me}_{4} \mathrm{~N}^{+}$and $\mathrm{Et}_{4} \mathrm{~N}^{+}$two estimates of volume are provided, the entry labelled $\mathrm{d}$ using radius and calculating $V$ as $4 \pi r^{3} / 3$ and the entry labelled c taken from crystallographically-based volume in Table 6 of ref. 1. This is to enable us to compare the results. ${ }^{f}$ Value appearing in ref. $67 .{ }^{g}$ Value appearing in ref. 51. ${ }^{h}$ Value appearing in ref. $66 .{ }^{i}$ Value appearing in ref. 71.

$\left(=(-47-185) / 2=-116 \mathrm{~kJ} \mathrm{~mol}^{-1}\right) \mathrm{nm}$ is then quite close to that given in the Born equation in the form of (7) (at $-110 \mathrm{~kJ}$ $\left.\mathrm{mol}^{-1} \mathrm{~nm}\right)$.

If we now use eqn (16) and (17) to regenerate the data used to form them, this gives us an idea of the accuracy which these rectilinear equations can be expected to give. Table 5 gives the figures from which we see that $\Delta_{\mathrm{hyd}} H^{\mathrm{O}}\left(\mathrm{X}^{-}, \mathrm{g}\right)$ is reproduced with an error of usually less than $9.7 \mathrm{~kJ} \mathrm{~mol}^{-1}$ (3.9\% error) whilst $\Delta_{\text {hyd }} G^{\mathrm{O}}\left(\mathrm{X}^{-}, \mathrm{g}\right)$ is more accurately reproduced with errors less than $4.0 \mathrm{~kJ} \mathrm{~mol}^{-1}$ (or 1.3\%). Now we direct eqn (16) and (17) towards prediction of values of $\Delta_{\mathrm{hyd}} H^{\mathrm{o}}\left(\mathrm{X}^{-}, \mathrm{g}\right)$ and $\Delta_{\mathrm{hyd}} G^{\mathrm{o}}\left(\mathrm{X}^{-}, \mathrm{g}\right)$ for the series of anions as listed in Table 6 .

Test of functional forms of volume. Hydration thermodynamic data sums in the form $\left[\Delta_{\mathrm{hyd}} H^{\mathrm{o}}\left(\mathrm{M}^{+}, \mathrm{g}\right)+\Delta_{\mathrm{hyd}} H^{\mathrm{o}}\left(\mathrm{X}^{-}, \mathrm{g}\right)\right]$ or of

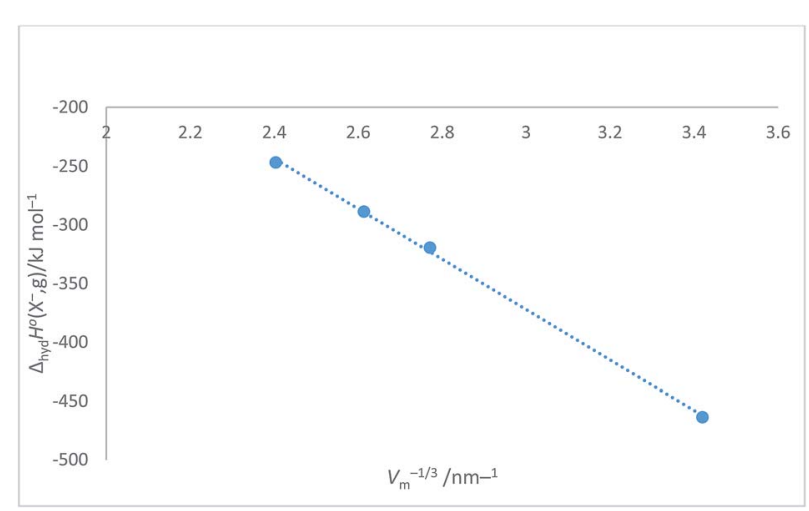

Fig. 5 Plot of $\Delta_{\text {hyd }} H^{\circ}\left(X^{-}, \mathrm{g}\right) / \mathrm{kJ} \mathrm{mol}^{-1}$ as ordinate versus $V_{\mathrm{m}}{ }^{-1 / 3} / \mathrm{nm}^{-1}$ as abscissa for halide ions listed in Table 4. $\Delta_{\text {hyd }} H^{\circ}\left(X^{-}, g\right)$ $=-214.7 V_{\mathrm{m}}{ }^{-1 / 3}+272.0, N=4, R^{2}=0.9992$.
$\left[\Delta_{\text {hyd }} G^{\mathrm{o}}\left(\mathrm{M}^{+}, \mathrm{g}\right)+\Delta_{\text {hyd }} G^{\mathrm{o}}\left(\mathrm{X}^{-}, \mathrm{g}\right)\right]$ may also be functions of volume which, in turn, could take various alternative forms: $\left[V_{\mathrm{m}}\left(\mathrm{M}^{+}\right)^{-1 / 3}\right.$ $\left.+V_{\mathrm{m}}\left(\mathrm{X}^{-}, \mathrm{g}\right)^{-1 / 3}\right],\left[V_{\mathrm{m}}\left(\mathrm{M}^{+}\right)+V_{\mathrm{m}}\left(\mathrm{X}^{-}, \mathrm{g}\right)\right]^{-1 / 3}, V_{\mathrm{m}}(\mathrm{MX})^{-1 / 3}$ or $\left[V_{\mathrm{m}}\left(\mathrm{M}^{+}\right)\right.$ $\left.+V_{\mathrm{m}}\left(\mathrm{X}^{-}, \mathrm{g}\right)\right]$, in order to produce rectilinear correlations. This is tested in the ESI Section S4 of this paper in which $\left[\Delta_{\text {hyd }} G^{\mathrm{o}}\left(\mathrm{M}^{+}, \mathrm{g}\right)\right.$ $\left.+\Delta_{\mathrm{hyd}} G^{\mathrm{o}}\left(\mathrm{Cl}^{-}, \mathrm{g}\right)\right]$ is plotted as ordinate versus $\left[V_{\mathrm{m}}\left(\mathrm{M}^{+}\right)+V_{\mathrm{m}}(-\right.$ $\left.\left.\mathrm{Cl}^{-}, \mathrm{g}\right)\right]^{-1 / 3}$ in Fig. S1, versus $\left[V_{\mathrm{m}}\left(\mathrm{M}^{+}\right)^{-1 / 3}+V_{\mathrm{m}}\left(\mathrm{Cl}^{-}, \mathrm{g}\right)^{-1 / 3}\right]$ in Fig. S2 and versus $V_{\mathrm{m}}(\mathrm{MCl})^{-1 / 3}$ in Fig. $\mathrm{S} 3$ and versus $\left[V_{\mathrm{m}}\left(\mathrm{M}^{+}\right)+\right.$ $\left.V_{\mathrm{m}}\left(\mathrm{X}^{-}, \mathrm{g}\right)\right]$ in Fig. $\mathrm{S} 4 . \dagger$

Fig. S2 is the only plot to show actual rectilinear characteristics and thus $\left[V_{\mathrm{m}}\left(\mathrm{M}^{+}\right)^{-1 / 3}+V_{\mathrm{m}}\left(\mathrm{X}^{-}, \mathrm{g}\right)^{-1 / 3}\right]$ is identified as the abscissa needed to plot versus hydration sums whilst the alternatives (Fig. S1, S3 and S4) are curves and are distinctly nonlinear with Fig. S3† being the curve closest to linearity.

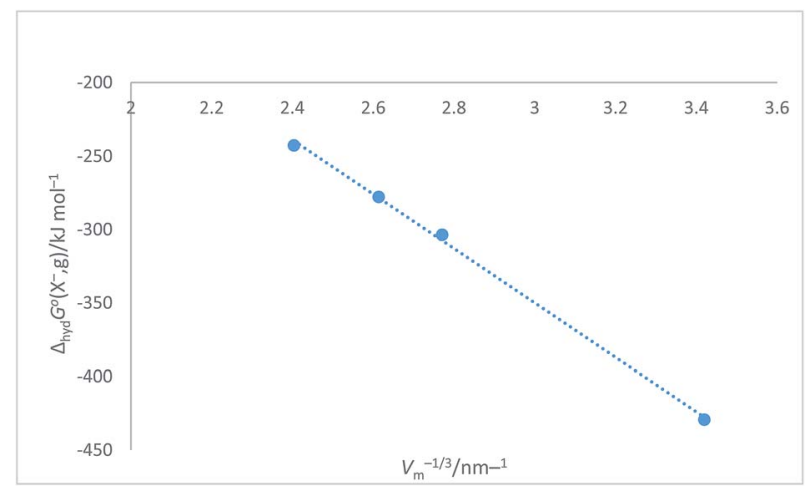

Fig. 6 Plot of $\Delta_{\text {hyd }} G^{\circ}\left(X^{-}, g\right) / \mathrm{kJ} \mathrm{mol}^{-1}$ as ordinate versus $V_{\mathrm{m}}{ }^{-1 / 3} / \mathrm{nm}^{-1}$ as abscissa for halide ions listed in Table 4. $\Delta_{\text {hyd }} G^{\circ}\left(X^{-}, g\right)$ $=-185.2 V_{\mathrm{m}}{ }^{-1 / 3}+205.7, N=4, R^{2}=0.9985$. 
Table 4 Values of absolute single-ion hydration enthalpies and free energies: $\Delta_{\text {hyd }} H^{\circ}\left(X^{-}, g\right)$ and $\Delta_{\text {hyd }} G^{\circ}\left(X^{-}, g\right)$ in kJ mol ${ }^{-1}$ for spherical halide ions together with associated radii, $r$ (in $\mathrm{nm}$ ) volume, $V_{\mathrm{m}}\left(=4 \pi r^{3} / 3\right)$ (in $\mathrm{nm}^{3}$ ) and $V_{\mathrm{m}}{ }^{-1 / 3} \mathrm{in} \mathrm{nm}$

\begin{tabular}{llllll}
\hline Cation & Radius, $r / \mathrm{nm}$ & Volume, $V_{\mathrm{m}} / \mathrm{nm}^{3}$ & $V_{\mathrm{m}}{ }^{-1 / 3} / \mathrm{nm}^{-1}$ & $\Delta_{\text {hyd }} H^{\mathrm{o}}\left(\mathrm{X}^{-}, \mathrm{g}\right) / \mathrm{kJ} \mathrm{mol}^{-1}$ & $\Delta_{\mathrm{hyd}} G^{\mathrm{o}}\left(\mathrm{X}^{-}, \mathrm{g}\right) / \mathrm{kJ} \mathrm{mol}^{-1}$ \\
\hline $\mathrm{F}^{-}$ & $0.133^{a}$ & 0.025 & 3.420 & -463.7 & -429.3 \\
$\mathrm{Cl}^{-}$ & $0.181^{a}$ & 0.047 & 2.771 & -319.5 & -303.5 \\
$\mathrm{Br}^{-}$ & $0.196^{a}$ & 0.056 & 2.614 & -288.7 & -277.7 \\
$\mathrm{I}^{-}$ & $0.220^{a}$ & 0.072 & 2.404 & -246.8 & -242.6
\end{tabular}

${ }^{a}$ Goldschmidt radius. ${ }^{58}$

Table 5 Test of the extent to which eqn (16) and (17) are capable of reproducing the absolute hydration data used to determine them ${ }^{a}$

\begin{tabular}{|c|c|c|c|c|c|c|c|}
\hline Anion & $V_{\mathrm{m}}^{-1 / 3} / \mathrm{nm}^{-1}$ & $\begin{array}{l}\Delta_{\text {hyd }} H^{\mathrm{o}}\left(\mathrm{X}^{-}, \mathrm{g}\right) / \\
\mathrm{kJ} \mathrm{mol}^{-1}\end{array}$ & $\begin{array}{l}\Delta_{\text {hyd }} H^{\mathrm{o}}\left(\mathrm{X}^{-}, \mathrm{g}\right) / \mathrm{kJ} \mathrm{mol}^{-1} \\
\text { predicted by eqn }(11)\end{array}$ & $\begin{array}{l}\% \text { age } \\
\text { difference }\end{array}$ & $\begin{array}{l}\Delta_{\mathrm{hyd}} G^{\mathrm{O}}\left(\mathrm{X}^{-}, \mathrm{g}\right) / \\
\mathrm{kJ} \mathrm{mol}^{-1}\end{array}$ & $\begin{array}{l}\Delta_{\text {hyd }} G^{\mathrm{O}}\left(\mathrm{X}^{-} \mathrm{g}\right) / \mathrm{kJ} \mathrm{mol}^{-1} \\
\text { predicted by eqn }(12)\end{array}$ & $\begin{array}{l}\% \text { age } \\
\text { difference }\end{array}$ \\
\hline $\mathrm{F}^{-}$ & 3.419952 & -463.7 & -455.3 & 1.8 & -429.3 & -427.7 & 0.4 \\
\hline $\mathrm{Br}^{-}$ & 2.61379 & -288.7 & -282.2 & 2.2 & -277.7 & -278.4 & -0.3 \\
\hline $\mathrm{I}^{-}$ & 2.403749 & -246.8 & -237.1 & 3.9 & -24 & -239.5 & +1.3 \\
\hline
\end{tabular}

${ }^{a}$ Volume data taken from Table 6 of ref. 1 (column 3 of Table 4).

Plot of $\left[\Delta_{\mathrm{hyd}} H^{\mathrm{o}}\left(\mathrm{M}^{+}, \mathrm{g}\right)+\Delta_{\mathrm{hyd}} H^{\mathrm{o}}\left(\mathrm{X}^{-}, \mathrm{g}\right)\right]$ versus $\left[V_{\mathrm{m}}\left(\mathrm{M}^{+}\right)^{-1 / 3}+\right.$ $\left.\boldsymbol{V}_{\mathbf{m}}\left(\mathbf{X}^{-}, \mathbf{g}\right)^{-\mathbf{1} / 3}\right]$. Eqn (18) and (20) summarise the good rectilinear correlations - of which eqn (19) is a specific example - resulting from plots of the sum of hydration enthalpies $\left[\Delta_{\text {hyd }} H^{\mathrm{O}}\left(\mathbf{M}^{+}, \mathrm{g}\right)+\right.$
$\left.\Delta_{\text {hyd }} H^{\mathrm{o}}\left(\mathrm{X}^{-}, \mathrm{g}\right)\right]$ versus, the sum of the inverse cube roots of the ions volumes $\left[V_{\mathrm{m}}\left(\mathrm{M}^{+}\right)^{-1 / 3}+V_{\mathrm{m}}\left(\mathrm{X}^{-}, \mathrm{g}\right)^{-1 / 3}\right]$ (see Section $\mathrm{S} 5$ and Tables S9-S11 $\uparrow$ for the data used) In these equations $\delta_{\mathrm{M}^{+}}$and $\delta_{\mathrm{X}^{-}}$ represent Kronecker deltas. If the ions being considered are, for

Table 6 Prediction of values of absolute single-ion hydration enthalpies and free energies of anions: $\Delta_{\text {hyd }} H^{\circ}\left(X^{-}, g\right)$ and $\Delta_{\text {hyd }} G^{\circ}\left(X^{-}, g\right)\left(\right.$ in $\mathrm{kJ}$ mol $\left.{ }^{-1}\right)$ for singly-charged cations

\begin{tabular}{|c|c|c|c|c|c|c|}
\hline Anion & $V_{\mathrm{m}} / \mathrm{nm}^{3 a}$ & $V_{\mathrm{m}}^{-1 / 3} / \mathrm{nm}^{-1}$ & $\begin{array}{l}\text { Estimated } \\
\Delta_{\text {hyd }} H^{\mathrm{o}}\left(\mathrm{X}^{-}, \mathrm{g}\right) / \mathrm{kJ} \mathrm{mol}^{-1} \\
\text { from eqn }(16)\end{array}$ & $\begin{array}{l}\text { Values of } \\
\Delta_{\text {hyd }} H^{\mathrm{O}}\left(\mathrm{x}^{-}, \mathrm{g}\right) / \mathrm{kJ} \mathrm{mol}^{-1} \\
\text { from other work }\end{array}$ & $\begin{array}{l}\text { Estimated } \\
\Delta_{\text {hyd }} G^{\mathrm{o}}\left(\mathrm{X}^{-}, \mathrm{g}\right) / \mathrm{kJ} \mathrm{mol}^{-1} \\
\text { from eqn }(17)\end{array}$ & $\begin{array}{l}\text { Values of } \\
\Delta_{\text {hyd }} G^{\mathrm{O}}\left(\mathrm{X}^{-}, \mathrm{g}\right) / \mathrm{kJ} \mathrm{mol}^{-1} \\
\text { from other work }\end{array}$ \\
\hline & 0.032 & & -404.3 & & -377.7 & $\begin{array}{l}-439.3^{c} \\
-438.1^{d}\end{array}$ \\
\hline \multirow{3}{*}{$\mathrm{SH}^{-}$} & & 3.1498 & & - & & $-439.3^{e}$ \\
\hline & & & & & & $-301.7^{d}$ \\
\hline & 0.057 & 2.5984 & -285.9 & - & -275.6 & $-295.8^{e}$ \\
\hline \multirow{3}{*}{$\begin{array}{l}\mathrm{SeH}^{-} \\
\mathrm{NH}_{2}{ }^{-}\end{array}$} & 0.070 & 2.4264 & -249.0 & - & -243.7 & - \\
\hline & & & & & & $-384.1^{c, e}$ \\
\hline & 0.043 & 2.8544 & -340.9 & - & -323.0 & $-397.5^{e}$ \\
\hline $\mathrm{O}_{2}^{-}$ & & & & & & $-355.2^{b}$ \\
\hline & 0.050 & 2.7144 & -310.8 & - & -297.0 & $-301.4^{e}$ \\
\hline $\mathrm{NCO}^{-}$ & 0.054 & 2.6457 & -296.1 & - & -284.3 & - \\
\hline $\mathrm{N}_{3}^{-}$ & 0.058 & 2.5834 & -282.7 & - & -272.8 & - \\
\hline $\mathrm{I}_{3}{ }^{-}$ & 0.171 & 1.8016 & -114.9 & - & -128.0 & - \\
\hline $\mathrm{HF}_{2}^{-}$ & 0.047 & 2.7710 & -323.0 & - & -307.5 & - \\
\hline $\mathrm{ClO}_{2}^{-}$ & 0.056 & 2.6138 & -289.2 & - & -278.4 & - \\
\hline $\mathrm{ClO}_{3}^{-}$ & 0.073 & 2.3927 & -241.8 & - & -237.5 & - \\
\hline $\mathrm{ClO}_{4}^{-}$ & 0.082 & 2.3018 & -222.2 & - & -220.6 & - \\
\hline $\mathrm{NO}_{2}^{-}$ & 0.055 & 4.3991 & -672.6 & - & -609.1 & - \\
\hline $\mathrm{NO}_{3}^{-}$ & 0.064 & 3.1809 & -411.0 & - & -383.4 & - \\
\hline
\end{tabular}

${ }^{a}$ Anions are non-spherical so all $V_{\mathrm{m}}$ data are taken from Table 6 of ref. $1 .{ }^{b}$ Value appearing in ref. $66 .{ }^{c}$ Value appearing in ref. $68 .{ }^{d}$ Value appearing in ref. 51. ${ }^{e}$ Value appearing in ref. 67. 
example, $\mathrm{M}^{+}=\mathrm{Na}^{+}$and $\mathrm{X}^{-}=\mathrm{Cl}^{-}$then: $\delta_{\mathrm{Na}^{+}}=\delta_{\mathrm{Cl}^{-}}=1$ whilst $\delta_{\mathrm{H}^{+}}=\delta_{\mathrm{Li}^{+}}=\delta_{\mathrm{K}^{+}}=\delta_{\mathrm{Rb}^{+}}=\delta_{\mathrm{Cs}^{+}}=\delta_{\mathrm{F}^{-}}=\delta_{\mathrm{Br}^{-}}=\delta_{\mathrm{I}^{-}}=0$. All the parallel rectilinear correlations represented by eqn (18) and (20) have at least an $R^{2}$ value of 0.9992 .

$$
\begin{aligned}
& {\left[\Delta_{\mathrm{hyd}} H^{\mathrm{o}}\left(\mathrm{M}^{+}, \mathrm{g}\right)+\delta_{\mathrm{F}^{-}} \Delta_{\mathrm{hyd}} H^{\mathrm{o}}\left(\mathrm{F}^{-}, \mathrm{g}\right)+\delta_{\mathrm{Cl}^{-}} \Delta_{\mathrm{hyd}} H^{\mathrm{o}}\left(\mathrm{Cl}^{-}, \mathrm{g}\right)\right.} \\
& \left.+\delta_{\mathrm{Br}^{-}} \Delta_{\mathrm{hyd}} H^{\mathrm{o}}\left(\mathrm{Br}^{-}, \mathrm{g}\right)+\delta_{\mathrm{I}^{-}} \Delta_{\mathrm{hyd}} H^{\mathrm{o}}\left(\mathrm{I}^{-}, \mathrm{g}\right)\right] \\
& =-48.208\left[V_{\mathrm{m}}\left(\mathrm{M}^{+}\right)^{-1 / 3}+\delta_{\mathrm{F}^{-}} V_{\mathrm{m}}\left(\mathrm{F}^{-}, \mathrm{g}\right)^{-1 / 3}+\delta_{\mathrm{Cl}^{-}} V_{\mathrm{m}}\left(\mathrm{Cl}^{-}, \mathrm{g}\right)^{-1 / 3}\right. \\
& \left.\quad+\delta_{\mathrm{Br}^{-}} V_{\mathrm{m}}\left(\mathrm{Br}^{-}, \mathrm{g}\right)^{-1 / 3}+\delta_{\mathrm{I}^{-}} V_{\mathrm{m}}\left(\mathrm{I}^{-}, \mathrm{g}\right)^{-1 / 3}\right]-453.45 \delta_{\mathrm{F}^{-}} \\
& \quad-343.3 \delta_{\mathrm{Cl}^{-}}-317.32 \delta_{\mathrm{Br}^{-}}-285.55 \delta_{\mathrm{I}^{-}}\left(R^{2}=0.9999\right)
\end{aligned}
$$

thus for NaBr: $\delta_{\mathrm{Na}^{+}}=\delta_{\mathrm{Br}^{-}}=1$ whilst $\delta_{\mathrm{H}^{+}}=\delta_{\mathrm{Li}^{+}}=\delta_{\mathrm{K}^{+}}=\delta_{\mathrm{Rb}^{+}}=\delta_{\mathrm{Cs}^{+}}$ $=\delta_{\mathrm{F}^{-}}=\delta_{\mathrm{Cl}^{-}}=\delta_{\mathrm{I}^{-}}=0$ and so, for example:

$$
\begin{aligned}
{\left[\Delta_{\mathrm{hyd}} H^{\mathrm{o}}\left(\mathrm{Na}^{+}, \mathrm{g}\right)+\Delta_{\mathrm{hyd}} H^{\mathrm{o}}\left(\mathrm{Br}^{-}, \mathrm{g}\right)\right] / \mathrm{kJ} \mathrm{mol}^{-1} } \\
=-48.208\left[V_{\mathrm{m}}\left(\mathrm{Na}^{+}\right)^{-1 / 3}+V_{\mathrm{m}}\left(\mathrm{Br}^{-}\right)^{-1 / 3}\right] / \mathrm{nm} \\
\quad-317.32\left(R^{2}=0.9999\right)
\end{aligned}
$$

using $\left[V_{\mathrm{m}}\left(\mathrm{Na}^{+}\right)^{-1 / 3}+V_{\mathrm{m}}\left(\mathrm{Br}^{-}\right)^{-1 / 3}\right]=8.9452 \mathrm{~nm}^{-1}$ yields a value for $\left[\Delta_{\text {hyd }} H^{\mathrm{O}}\left(\mathrm{Na}^{+}, \mathrm{g}\right)+\Delta_{\text {hyd }} H^{\mathrm{O}}\left(\mathrm{Br}^{-}, \mathrm{g}\right)\right] / \mathrm{kJ} \mathrm{mol}^{-1}=-749 \mathrm{~kJ} \mathrm{~mol}^{-1}$ or only a $0.4 \%$ error and also:

$\left[\delta_{\mathrm{H}^{+}} \Delta_{\mathrm{hyd}} H^{\mathrm{o}}\left(\mathrm{H}^{+}, \mathrm{g}\right)+\delta_{\mathrm{Li}^{+}} \Delta_{\mathrm{hyd}} H^{\mathrm{o}}\left(\mathrm{Li}^{+}, \mathrm{g}\right)+\delta_{\mathrm{Na}^{+}} \Delta_{\mathrm{hyd}} H^{\mathrm{o}}\left(\mathrm{Na}^{+}, \mathrm{g}\right)\right.$ $+\delta_{\mathrm{K}^{+}} \Delta_{\mathrm{hyd}} H^{\mathrm{o}}\left(\mathrm{K}^{+}, \mathrm{g}\right)+\delta_{\mathrm{Rb}^{+}} \Delta_{\mathrm{hyd}} H^{\mathrm{o}}\left(\mathrm{Rb}^{+}, \mathrm{g}\right)+\delta_{\mathrm{Cs}^{+}} \Delta_{\mathrm{hyd}} H^{\mathrm{o}}\left(\mathrm{Cs}^{+}, \mathrm{g}\right)$

$\left.+\Delta_{\mathrm{hyd}} H^{\mathrm{o}}\left(\mathrm{X}^{-}, \mathrm{g}\right)\right]$

$=-214.69\left[\delta_{\mathrm{H}^{+}} V_{\mathrm{m}}\left(\mathrm{H}^{+}\right)^{-1 / 3}+\delta_{\mathrm{Li}^{+}} V_{\mathrm{m}}\left(\mathrm{Li}^{+}\right)^{-1 / 3}+\delta_{\mathrm{Na}^{+}} V_{\mathrm{m}}\left(\mathrm{Na}^{+}\right)^{-1 / 3}\right.$

$+\delta_{\mathrm{K}^{+}} V_{\mathrm{m}}\left(\mathrm{K}^{+}\right)^{-1 / 3}+\delta_{\mathrm{Rb}^{+}} V_{\mathrm{m}}\left(\mathrm{Rb}^{+}\right)^{-1 / 3}+\delta_{\mathrm{Cs}^{+}} V_{\mathrm{m}}\left(\mathrm{Cs}^{+}\right)^{-1 / 3}$

$\left.+{ }^{-} V_{\mathrm{m}}\left(\mathrm{X}^{-}, \mathrm{g}\right)^{-1 / 3}\right]+3560.6 \delta_{\mathrm{H}^{+}}+1569.4 \delta_{\mathrm{Li}^{+}}+1167.9 \delta_{\mathrm{Na}^{+}}$

$+892.8 \delta_{\mathrm{K}^{+}}+810.5 \delta_{\mathrm{Rb}^{+}}+748.4 \delta_{\mathrm{Cs}^{+}}\left(R^{2}=0.9992\right)$

which gives an alternative, equally valid, equation to that of eqn (19) in the form:

$$
\begin{aligned}
{\left[\Delta_{\mathrm{hyd}} H^{\mathrm{o}}\left(\mathrm{Na}^{+}, \mathrm{g}\right)+\Delta_{\mathrm{hyd}} H^{\mathrm{o}}\left(\mathrm{Br}^{-}, \mathrm{g}\right)\right] / \mathrm{kJ} \mathrm{mol}^{-1} } \\
=-214.69\left[V_{\mathrm{m}}\left(\mathrm{Na}^{+}\right)^{-1 / 3}+V_{\mathrm{m}}\left(\mathrm{Br}^{-}\right)^{-1 / 3}\right] / \mathrm{nm} \\
+1167.9\left(R^{2}=0.9992\right)
\end{aligned}
$$

using a test input of $\left[V_{\mathrm{m}}\left(\mathrm{Na}^{+}\right)^{-1 / 3}+V_{\mathrm{m}}\left(\mathrm{Br}^{-}\right)^{-1 / 3}\right]=8.9452 \mathrm{~nm}^{-1}$ yields a value for $\left[\Delta_{\text {hyd }} H^{\mathrm{o}}\left(\mathrm{Na}^{+}, \mathrm{g}\right)+\Delta_{\mathrm{hyd}} H^{\mathrm{o}}\left(\mathrm{Br}^{-}, \mathrm{g}\right)\right]=-752 \mathrm{~kJ}$ $\mathrm{mol}^{-1}$ with no error. The two test calculations confirm the satisfactory nature of the correlations. The full set of equations, of which (18) and (20) are summaries are to be found in the ESI Section S6, eqn (S8)-(S17) $\dagger$

Plots of $\left[\Delta_{\text {hyd }} G^{\mathrm{O}}\left(\mathrm{M}^{+}, \mathrm{g}\right)+\Delta_{\mathrm{hyd}} G^{\mathrm{O}}\left(\mathrm{X}^{-}, \mathrm{g}\right)\right]$ versus $\left[V_{\mathrm{m}}\left(\mathrm{M}^{+}\right)^{-1 / 3}+\right.$ $\left.V_{\mathrm{m}}\left(\mathrm{X}^{-}, \mathrm{g}\right)^{-1 / 3}\right]$.

Eqn (22) and (23) summarize the good rectilinear correlations resulting from plots of the sum of hydration free energies $\left[\Delta_{\text {hyd }} G^{\mathrm{O}}\left(\mathrm{M}^{+}, \mathrm{g}\right)+\Delta_{\text {hyd }} G^{\mathrm{o}}\left(\mathrm{X}^{-}, \mathrm{g}\right)\right]$ versus, the sum of the inverse cube roots of the ions volumes $\left[V_{\mathrm{m}}\left(\mathrm{M}^{+}\right)^{-1 / 3}+V_{\mathrm{m}}\left(\mathrm{X}^{-}, \mathrm{g}\right)^{-1 / 3}\right]$. All the parallel rectilinear correlations represented by eqn (22) and (23) have at least an $R^{2}$ value of 0.9993 .

$$
\begin{aligned}
{\left[\Delta_{\mathrm{hyd}} G^{\mathrm{o}}\left(\mathrm{M}^{+}, \mathrm{g}\right)+\right.} & \delta_{\mathrm{F}^{-}} \Delta_{\mathrm{hyd}} G^{\mathrm{o}}\left(\mathrm{F}^{-}, \mathrm{g}\right)+\delta_{\mathrm{Cl}^{-}} \Delta_{\mathrm{hyd}} G^{\mathrm{o}}\left(\mathrm{Cl}^{-}, \mathrm{g}\right) \\
& \left.+\delta_{\mathrm{Br}^{-}} \Delta_{\mathrm{hyd}} G^{\mathrm{o}}\left(\mathrm{Br}^{-}, \mathrm{g}\right)+\delta_{\mathrm{I}^{-}} \Delta_{\mathrm{hyd}} G^{\mathrm{o}}\left(\mathrm{I}^{-}, \mathrm{g}\right)\right] \\
= & -47.057\left[V_{\mathrm{m}}\left(\mathrm{M}^{+}\right)^{-1 / 3}+\delta_{\mathrm{F}^{-}} V_{\mathrm{m}}\left(\mathrm{F}^{-}, \mathrm{g}\right)^{-1 / 3}\right. \\
& +\delta_{\mathrm{Cl}^{-}} V_{\mathrm{m}}\left(\mathrm{Cl}^{-}, \mathrm{g}\right)^{-1 / 3}+\delta_{\mathrm{Br}^{-}} V_{\mathrm{m}}\left(\mathrm{Br}^{-}, \mathrm{g}\right)^{-1 / 3} \\
& \left.+\delta_{\mathrm{I}^{-}} V_{\mathrm{m}}\left(\mathrm{I}^{-}, \mathrm{g}\right)^{-1 / 3}\right]-396.82 \delta_{\mathrm{F}^{-}}-301.56 \delta_{\mathrm{Cl}^{-}} \\
& -283.16 \delta_{\mathrm{Br}^{-}}-254.85 \delta_{\mathrm{I}^{-}}\left(R^{2}=0.9996\right)
\end{aligned}
$$

and also:

$$
\begin{aligned}
& {\left[\delta_{\mathrm{H}^{+}} \Delta_{\mathrm{hyd}} G^{\mathrm{o}}\left(\mathrm{H}^{+}, \mathrm{g}\right)+\delta_{\mathrm{Li}^{+}} \Delta_{\mathrm{hyd}} G^{\mathrm{o}}\left(\mathrm{Li}^{+}, \mathrm{g}\right)+\delta_{\mathrm{Na}^{+}} \Delta_{\mathrm{hyd}} G^{\mathrm{o}}\left(\mathrm{Na}^{+}, \mathrm{g}\right)\right.} \\
+ & \delta_{\mathrm{K}^{+}} \Delta_{\mathrm{hyd}} G^{\mathrm{o}}\left(\mathrm{K}^{+}, \mathrm{g}\right)+\delta_{\mathrm{Rb}^{+}} \Delta_{\mathrm{hyd}} G^{\mathrm{o}}\left(\mathrm{Rb}^{+}, \mathrm{g}\right)+\delta_{\mathrm{Cs}^{+}} \Delta_{\mathrm{hyd}} G^{\mathrm{o}}\left(\mathrm{Cs}^{+}, \mathrm{g}\right) \\
+ & \left.-\Delta_{\mathrm{hyd}} G^{\mathrm{o}}\left(\mathrm{X}^{-}, \mathrm{g}\right)\right]=-187.34\left[\delta_{\mathrm{H}^{+}} V_{\mathrm{m}}\left(\mathrm{H}^{+}\right)^{-1 / 3}+\delta_{\mathrm{Li}^{+}} V_{\mathrm{m}}\left(\mathrm{Li}^{+}\right)^{-1 / 3}\right. \\
+ & \delta_{\mathrm{Na}^{+}} V_{\mathrm{m}}\left(\mathrm{Na}^{+}\right)^{-1 / 3}+\delta_{\mathrm{K}^{+}} V_{\mathrm{m}}\left(\mathrm{K}^{+}\right)^{-1 / 3}+\delta_{\mathrm{Rb}^{+}} V_{\mathrm{m}}\left(\mathrm{Rb}^{+}\right)^{-1 / 3} \\
+ & \left.\delta_{\mathrm{Cs}^{+}} V_{\mathrm{m}}\left(\mathrm{Cs}^{+}\right)^{-1 / 3}+-V_{\mathrm{m}}\left(\mathrm{X}^{-}, \mathrm{g}\right)^{-1 / 3}\right]+2981.4 \delta_{\mathrm{H}^{+}} \\
+ & \left.1319.8 \delta\right|_{\mathrm{Li}^{+}}+974.9 \delta_{\mathrm{Na}^{+}}+734.3 \delta_{\mathrm{K}^{+}}+663.1 \delta_{\mathrm{Rb}^{+}} \\
+ & 610.4 \delta_{\mathrm{Cs}^{+}}\left(R^{2}=0.9993\right)
\end{aligned}
$$

The full set of individual equations are given in Section S7 of the ESI which lists eqn (S18)-(S27). $\uparrow$ Note also that the gradients of the lines (18)-(22) are identical and in the case of eqn (23) very close to those of eqn (9), (10), (16) and (17).

A sample of the graphical plot is to be found for $\mathrm{MCl}$ salts ( $\mathrm{M}$ $=\mathrm{Li}-\mathrm{Cs}$ ) in Fig. $\mathrm{S} 2 \uparrow$ in Section $\mathrm{S} 4$ and other alkali halide salts have very similar plots.

From the above analyses the uniqueness of the $V_{\mathrm{m}}{ }^{-1 / 3}$ functions has been demonstrated and we reach our main conclusion that VBT clearly applies to the hydration thermodynamic data tested thus far.

\section{Examination of thermodynamic data from literature sources and the use of $V^{-1 / 3}$ as a correlation parameter}

In what follows we retain the notation used in the publications highlighted for consideration and note when this corresponds to an (alternative) notation used earlier in the paper. Listed in Tables 7 and 8 are the conventional aqueous solvation free energies of gaseous cations and anions, determined using the eqn (13) and (16) of ref. 51 by use of $\mathrm{p} K_{\mathrm{a}}$ values. Because this represents a large database of thermochemical solvation values we examine how this data behaves when plotted versus $V^{-1 / 3}$. Statistics applied to the end results tells us that there is virtually no probability of being wrong in assuming that a linear correlation exists between the solvation free energies and $V^{-1 / 3}$. Hofmann's volumes ${ }^{61}$ have been employed in the absence of direct volume data.

The plot in Fig. 7 for organic cations can be examined ${ }^{73}$ to determine the probability, $P$, of being wrong in assuming a linear correlation exists between $\Delta G_{\mathrm{S}}^{\mathrm{O}}\left(\mathrm{BH}^{+}\right) / \mathrm{kJ} \mathrm{mol}^{-1}$ and $V_{\mathrm{m}}\left(\mathrm{BH}^{+}\right) / \mathrm{nm}^{3}$. The Student's $t$ (2-sided) is first calculated ${ }^{72}$ and found to be $9.98, N=50$ data

$$
t(2 \text {-sided })=\left[R^{2}(N-2) /\left(1-R^{2}\right)\right]^{1 / 2}
$$

points and $P=0.00001$ showing that it is correct to assume that correlation exists between the thermodynamic parameter and the inverse cube root of the volume. There is considerable scatter which, to some extent, is probably due to the use of the Hofmann volumes. The nature of the organic cations considered (see Table 7) is such that many have strong internal interactions between functional groups which cannot be reflected in just considering elementary atom volumes making up the formula unit. The analytical form of the rectilinear fit takes the form:

$$
\begin{aligned}
\Delta G_{\mathrm{S}}^{\mathrm{o}}\left(\mathrm{BH}^{+}\right) / \mathrm{kJ} \mathrm{mol}^{-1}= & -98.0\left[V_{\mathrm{m}}\left(\mathrm{BH}^{+}\right) / \mathrm{nm}^{3}\right] \\
& +1027.1\left(N=50, R^{2}=0.6747\right)
\end{aligned}
$$


Table 7 Assembly of cation values for $\Delta G_{S}^{0, c o n}\left(\mathrm{BH}^{+}\right) / \mathrm{kJ} \mathrm{mol}^{-1}$ from ref. 51 and Hofmann volumes $V_{\mathrm{m}}$ to make plot in Fig. 7. The rectilinear regression equation of best fit is used to predict single-ion free energy values for cations, $\Delta G_{\mathrm{S}}^{\mathrm{o}, c o n}\left(\mathrm{BH}^{+}\right) / \mathrm{kJ} \mathrm{mol}^{-1}$ using eqn $(24)$ of best fit. $\Delta G_{S}^{\circ}\left(B^{+}\right) / \mathrm{kJ} \mathrm{mol}^{-1}=-98.0\left[V_{\mathrm{m}}\left(\mathrm{BH}^{+}\right) / \mathrm{nm}^{3}\right]+1027.1\left(\mathrm{~N}=50, R^{2}=0.6747\right)(24)$

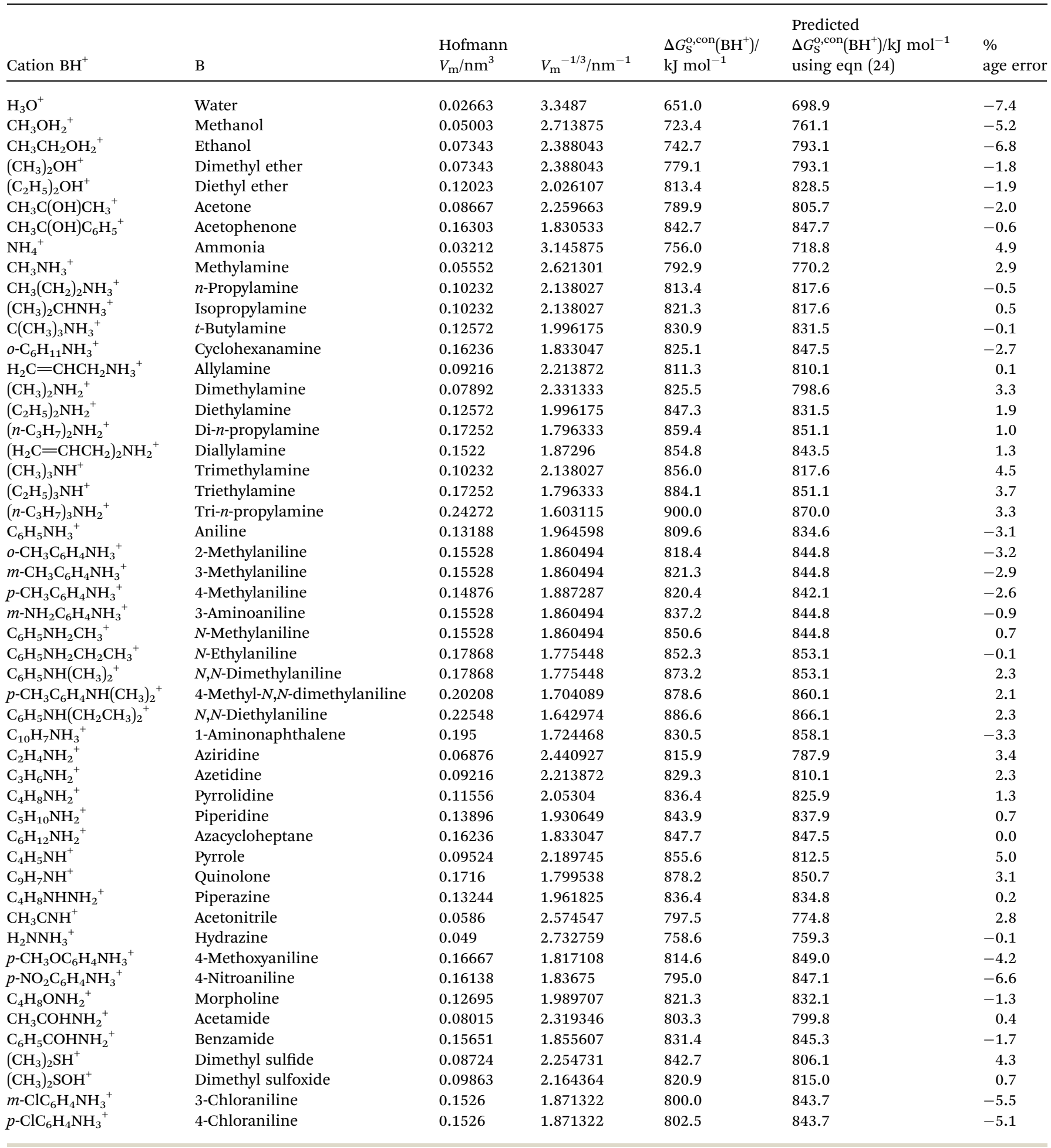

The plot in Fig. 8 for organic anions can be used to investigate the nature of any correlation that might exist between $\Delta G_{\mathrm{S}}^{\mathrm{o}}\left(\mathrm{A}^{-}\right) / \mathrm{kJ} \mathrm{mol}^{-1}$ and $V_{\mathrm{m}}\left(\mathrm{A}^{-}\right)^{-1 / 3} / \mathrm{nm}^{-1}$ Even though the regression coefficient, $R^{2}$, is quite low and there is considerable scatter we can infer that the correlation is valid. The Student's $t$ (2-sided) is first calculated ${ }^{72,73}$ (eqn (24)) and found to be 92.741 with $N=57$ data points, $R^{2}=0.2725$ (eqn (26)) and $P$, the probability that it is wrong to assume the correlation is found to 
Table 8 Assembly of anion values for $\Delta G_{S}^{0, c o n}\left(A^{-}\right) / \mathrm{kJ} \mathrm{mol}^{-1}$ from ref. 51 and Hofmann volumes $V_{m}$ to make plot in Fig. 8 . The rectilinear regression equation of best fit is used to predict single-ion free energy values for anions, $\Delta G_{\mathrm{S}}^{\circ}, \mathrm{con}\left(\mathrm{A}^{-}\right) / \mathrm{kJ} \mathrm{mol}^{-1}$ using eqn (25) of best fit. $\Delta G_{\mathrm{S}}^{\circ}\left(A^{-}\right) /$ $\mathrm{kJ} \mathrm{mol}{ }^{-1}=-54.36\left[\mathrm{~V}_{\mathrm{m}}\left(\mathrm{A}^{-}\right) / \mathrm{nm}^{3}\right]-1298.1\left(\mathrm{~N}=57, R^{2}=0.2725\right)(25)$

\begin{tabular}{|c|c|c|c|c|c|c|}
\hline $\mathrm{HO}_{2}^{-}$ & Hydrogen peroxide & 0.02786 & 3.298676 & -1519.6 & -1477.4 & 2.8 \\
\hline $\mathrm{O}_{2}^{-}$ & Hydroperoxyl radical & 0.046 & 2.79092 & -1461.1 & -1449.8 & 0.8 \\
\hline $\mathrm{HS}^{-}$ & Hydrogen sulfide & 0.057 & 2.598414 & -1414.2 & -1439.4 & -1.8 \\
\hline $\mathrm{CH}_{3} \mathrm{O}^{-}$ & Methanol & 0.03987 & 2.927192 & -1510 & -1457.2 & 3.5 \\
\hline $\mathrm{C}_{2} \mathrm{H}_{5} \mathrm{O}^{-}$ & Ethanol & 0.06327 & 2.509578 & -1492 & -1434.5 & 3.9 \\
\hline $\mathrm{C}_{3} \mathrm{H}_{7} \mathrm{O}^{-}$ & 1-Propanol & 0.08667 & 2.259663 & -1482 & -1420.9 & 4.1 \\
\hline $\mathrm{C}_{3} \mathrm{H}_{7} \mathrm{O}^{-}$ & 2-Propanol & 0.08667 & 2.259663 & -1473.6 & -1420.9 & 3.6 \\
\hline $\mathrm{C}_{4} \mathrm{H}_{9} \mathrm{O}^{-}$ & 2-Butanol & 0.11007 & 2.086621 & -1464.8 & -1411.5 & 3.6 \\
\hline $\mathrm{C}_{4} \mathrm{H}_{9} \mathrm{O}^{-}$ & $t$-Butanol & 0.11007 & 2.086621 & -1456.9 & -1411.5 & 3.1 \\
\hline $\mathrm{C}_{2} \mathrm{~F}_{3} \mathrm{H}_{2} \mathrm{O}^{-}$ & 2,2,2-Trifluoroethanol & 0.08154 & 2.306091 & -1436.8 & -1423.5 & 0.9 \\
\hline $\mathrm{C}_{3} \mathrm{HF}_{6} \mathrm{O}^{-}$ & $1,1,1,3,3,3$-Hexafluoropropan-2-ol & 0.12321 & 2.009639 & -1386.6 & -1407.4 & -1.5 \\
\hline $\mathrm{CH}_{3} \mathrm{O}_{2}^{-}$ & Methyl hydroperoxide & 0.05126 & 2.691992 & -1502.5 & -1444.4 & 3.9 \\
\hline $\mathrm{C}_{2} \mathrm{H}_{5} \mathrm{O}_{2}^{-}$ & Ethyl hydroperoxide & 0.07466 & 2.374856 & -1485.7 & -1427.2 & 3.9 \\
\hline $\mathrm{CHO}_{2}^{-}$ & Formic acid & 0.0411 & 2.897695 & -1431.3 & -1455.6 & -1.7 \\
\hline $\mathrm{C}_{2} \mathrm{H}_{3} \mathrm{O}_{2}{ }^{-}$ & Acetic acid & 0.0645 & 2.493523 & -1437.2 & -1433.7 & 0.2 \\
\hline $\mathrm{C}_{2} \mathrm{H}_{3} \mathrm{O}_{2}^{-}$ & Propanoic acid & 0.0645 & 2.493523 & -1431.3 & -1433.7 & -0.2 \\
\hline $\mathrm{C}_{6} \mathrm{H}_{11} \mathrm{O}_{2}^{-}$ & Hexanoic acid & 0.1581 & 1.849365 & -1424.7 & -1398.6 & 1.8 \\
\hline $\mathrm{C}_{3} \mathrm{H}_{3} \mathrm{O}_{2}{ }^{-}$ & Acrylic acid & 0.07774 & 2.343069 & -1422.1 & -1425.5 & -0.2 \\
\hline $\mathrm{C}_{2} \mathrm{H}_{2} \mathrm{ClO}_{2}^{-}$ & Pyruvic acid & 0.08522 & 2.272407 & -1399.1 & -1421.6 & -1.6 \\
\hline $\mathrm{C}_{2} \mathrm{HCl}_{2} \mathrm{O}_{2}^{-}$ & Chloroacetic acid & 0.10594 & 2.113392 & -1404.2 & -1413 & -0.6 \\
\hline $\mathrm{C}_{2} \mathrm{HCl}_{2} \mathrm{O}_{2}^{-}$ & Dichloroacetic acid & 0.08277 & 2.294611 & -1373.2 & -1422.8 & -3.6 \\
\hline $\mathrm{C}_{6} \mathrm{H}_{4} \mathrm{NO}_{3}^{-}$ & 2-Nitrophenol & 0.14573 & 1.900277 & -1364 & -1401.4 & -2.7 \\
\hline $\mathrm{C}_{6} \mathrm{H}_{4} \mathrm{NO}_{3}^{-}$ & 3-Nitrophenol & 0.14573 & 1.900277 & -1371.5 & -1401.4 & -2.2 \\
\hline $\mathrm{C}_{6} \mathrm{H}_{4} \mathrm{NO}_{3}^{-}$ & 4-Nitrophenol & 0.14573 & 1.900277 & -1354.4 & -1401.4 & -3.5 \\
\hline $\mathrm{C}_{6} \mathrm{H}_{4} \mathrm{ClO}^{-}$ & 2-Chlorophenol & 0.13695 & 1.940049 & -1389.1 & -1403.6 & -1 \\
\hline $\mathrm{C}_{6} \mathrm{H}_{4} \mathrm{ClO}^{-}$ & 4-Chlorophenol & 0.13695 & 1.940049 & -1388.7 & -1403.6 & -1.1 \\
\hline $\mathrm{C}_{2} \mathrm{H}_{3} \mathrm{O}_{2}^{-}$ & Acetaldehyde & 0.0645 & 2.493523 & -1432.6 & -1433.7 & -0.1 \\
\hline $\mathrm{C}_{3} \mathrm{H}_{5} \mathrm{O}^{-}$ & Acetone & 0.07651 & 2.355559 & -1431.3 & -1426.2 & 0.4 \\
\hline $\mathrm{C}_{5} \mathrm{H}_{9} \mathrm{O}^{-}$ & 3-Pentanone & 0.12331 & 2.009095 & -1420.9 & -1407.3 & 1 \\
\hline $\mathrm{CHN}_{2}^{-}$ & Cyanamide & 0.04192 & 2.878677 & -1414.6 & -1454.6 & -2.8 \\
\hline $\mathrm{C}_{2} \mathrm{H}_{2} \mathrm{~N}^{-}$ & Acetonitrile & 0.04844 & 2.743249 & -1391.2 & -1447.2 & -4 \\
\hline $\mathrm{C}_{6} \mathrm{H}_{6} \mathrm{~N}^{-}$ & Aniline & 0.12172 & 2.017806 & -1375.7 & -1407.8 & -2.3 \\
\hline $\mathrm{C}_{6} \mathrm{H}_{6} \mathrm{~N}_{2} \mathrm{O}_{2}^{-}$ & 4-Nitroaniline & 0.1563 & 1.856438 & -1352.7 & -1399 & -3.4 \\
\hline $\mathrm{C}_{12} \mathrm{H}_{10} \mathrm{~N}^{-}$ & Diphenylamine & 0.23287 & 1.625407 & -1341 & -1386.5 & -3.4 \\
\hline $\mathrm{C}_{2} \mathrm{H}_{4} \mathrm{NO}^{-}$ & Acetamide & 0.06999 & 2.426543 & -1448.1 & -1430 & 1.2 \\
\hline $\mathrm{CH}_{2} \mathrm{NO}_{2}^{-}$ & Nitromethane & 0.05798 & 2.583691 & -1432.6 & -1438.6 & -0.4 \\
\hline $\mathrm{CH}_{3} \mathrm{~S}^{-}$ & Methanethiol & 0.05368 & 2.650915 & -1421.3 & -1442.2 & -1.5 \\
\hline $\mathrm{C}_{2} \mathrm{H}_{5} \mathrm{~S}^{-}$ & Ethanethiol & 0.02712 & 3.328406 & -1412.9 & -1479 & -4.7 \\
\hline $\mathrm{C}_{3} \mathrm{H}_{7} \mathrm{~S}^{-}$ & 1-Propanethiol & 0.10048 & 2.150999 & -1407.5 & -1415 & -0.5 \\
\hline $\mathrm{C}_{6} \mathrm{H}_{5} \mathrm{~S}^{-}$ & Thiophenol & 0.13004 & 1.973821 & -1377.8 & -1405.4 & -2 \\
\hline $\mathrm{C}_{2} \mathrm{H}_{5} \mathrm{OS}^{-}$ & Dimethyl sulfoxide & 0.08847 & 2.244233 & -1395.8 & -1420.1 & -1.7 \\
\hline $\mathrm{CCl}_{3}^{-}$ & Chloroform & 0.09064 & 2.226179 & -1338.9 & -1419.1 & -6 \\
\hline
\end{tabular}




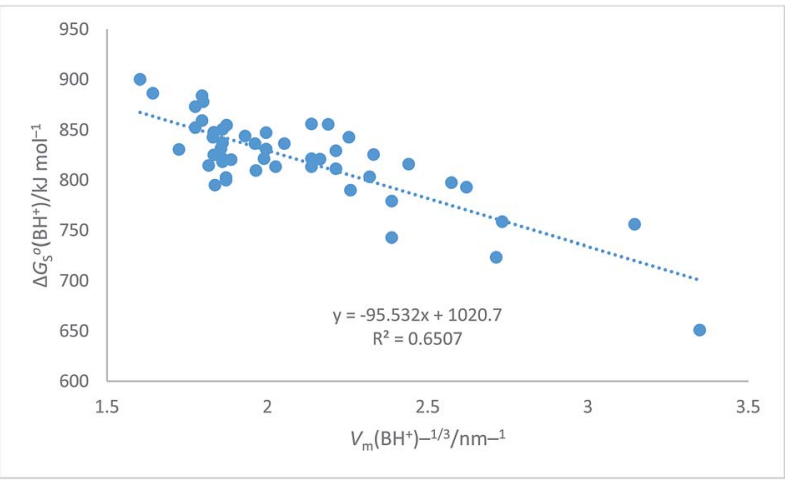

Fig. 7 Plot of conventional aqueous solvation free energies of cations for a standard state concentration of $1 \mathrm{~mol} \mathrm{dm}^{-3}$ in both the gas and aqueous phases, $\Delta G_{S}^{O}\left(\mathrm{BH}^{+}\right) / \mathrm{kJ} \mathrm{mol}^{-1}$ taken from Table 2 of ref. 51 as ordinate versus $V_{m}\left(\mathrm{BH}^{+}\right)^{-1 / 3} / \mathrm{nm}^{-1}$ (calculated from Hofmann volumes ${ }^{29}$ ) as abscissa.

be equal to 0.0082 . This can be interpreted to mean that in only 8 instances in 1000 would one be wrong to infer a correlation existed between the thermodynamic parameter and the inverse cube root of the volume. There is even more scatter in the case of these anions as compared to Fig. 7 which, to some extent, is probably made worse due to the use of the Hofmann volumes. Hofmann mentions that additional terms can be added to improve his procedure and take account of the local environment of individual atoms. These terms depend on the nature of the functional groups present and is more complicated to take account of and is, of course, based on significantly more parameters than the simple approach we have adopted. Nor has the effect of the charge been considered. The analytical form of the rectilinear fit takes the form (Fig. 8):

$$
\begin{aligned}
\Delta G_{\mathrm{S}}^{\mathrm{o}}\left(\mathrm{A}^{-}\right) / \mathrm{kJ} \mathrm{mol}^{-1}= & -54.36\left[V_{\mathrm{m}}\left(\mathrm{A}^{-}\right) / \mathrm{nm}^{3}\right]^{-1 / 3} \\
& -1298.1\left(N=57, R^{2}=0.2725\right)
\end{aligned}
$$

The above two correlations, although found to be satisfactory, represent extremes and could possibly be improved and scatter reduced if density data (see eqn (1)) were employed to

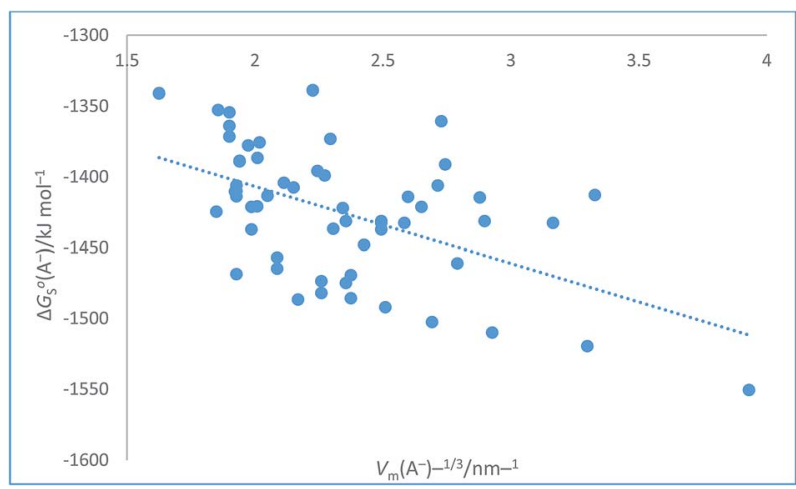

Fig. 8 Plot of conventional aqueous solvation free energies of anions for a standard state concentration of $1 \mathrm{~mol} \mathrm{dm}^{-3}$ in both the gas and aqueous phases, $\Delta G_{S}^{\circ}\left(A^{-}\right) / \mathrm{kJ} \mathrm{mol}^{-1}$ taken from Table 2 of ref. 51 as ordinate versus $V_{m}\left(A^{-}\right)^{-1 / 3} / \mathrm{nm}^{-1}$ (calculated from Hofmann volumes ${ }^{29}$ ) as abscissa. estimate volume of each of the materials. The reason they were selected for study was that they offered a large dataset which also conformed to being an example of the newer generation of hydration data.

Turning now to a further application, in the ESI Section Table S12 $\uparrow$ presents data for $\left[\Delta G_{\mathrm{aq}}^{\mathrm{o}}\left(\mathrm{M}^{+}, \mathrm{g}\right)+\Delta G_{\mathrm{aq}}^{\mathrm{o}}\left(\mathrm{X}^{-}, \mathrm{g}\right)\right] / \mathrm{kJ} \mathrm{mol}^{-1}$ (which is equivalent to $\left[\Delta G_{\text {hyd }}^{\mathrm{o}}\left(\mathrm{M}^{+}, \mathrm{g}\right)+\Delta G_{\text {hyd }}^{\mathrm{o}}\left(\mathrm{X}^{-}, \mathrm{g}\right)\right]$ adopting our earlier notation) as found in Table 1 of ref. 52 for the alkali halides. The data in Table $\mathrm{S} 12$ can be compared to that obtained in Table S9 obtained using eqn (S6) or (S7) in Section S3 and will be seen to vary slightly from data derived as state of the art in Table S9. $\dagger\left[\Delta G_{\text {aq }}^{\mathrm{o}}\left(\mathrm{M}^{+}, \mathrm{g}\right)+\Delta G_{\mathrm{aq}}^{\mathrm{o}}\left(\mathrm{X}^{-}, \mathrm{g}\right)\right]$ represents the free energy change brought about by placing a pair of separate and oppositely charged gaseous ions into water at $298 \mathrm{~K}$. Results in Table $\mathrm{S} 12 \dagger$ are the results of Tissendier et al. computations. Fig. 9 displays a plot of the whole of this alkali halide solvation free energy data $=\left[\Delta G_{\mathrm{aq}}^{\mathrm{o}}\left(\mathrm{M}^{+}, \mathrm{g}\right)+\Delta G_{\mathrm{aq}}^{\mathrm{o}}\left(\mathrm{X}^{-}, \mathrm{g}\right)\right]$ as ordinate versus $V(\mathbf{M X})^{-1 / 3}$ as abscissa.

The rectilinear fit is represented by eqn (27) which takes the analytical form

$$
\begin{aligned}
& \Delta G_{\mathrm{aq}}^{\mathrm{o}}\left(\mathrm{A}^{+}+\mathrm{B}^{-}\right)=\left[\Delta G_{\mathrm{aq}}^{\mathrm{o}}\left(\mathrm{M}^{+}, \mathrm{g}\right)+\Delta G_{\mathrm{aq}}^{\mathrm{o}}\left(\mathrm{X}^{-}, \mathrm{g}\right)\right] \\
& \quad=-245.38 V(\mathrm{MX})^{-1 / 3}-63.607\left(N=20, R^{2}=0.8420\right)
\end{aligned}
$$

Additional to this we can take sections of the data and plot it versus $V(\mathrm{MX})^{-1 / 3}$. The following rectilinear equations result:

For the individual alkali metal (except Cs) salts:

$$
\begin{aligned}
{\left[\Delta G_{\mathrm{aq}}^{\mathrm{o}}\left(\mathrm{Li}^{+}, \mathrm{g}\right)\right.} & \left.+\Delta G_{\mathrm{aq}}^{\mathrm{o}}\left(\mathrm{X}^{-}, \mathrm{g}\right)\right] / \mathrm{kJ} \mathrm{mol}^{-1}=-144.73 V(\mathrm{LiX})^{-1 / 3} \\
& -388.01\left(N=4, R^{2}=1\right) \\
{\left[\Delta G_{\mathrm{aq}}^{\mathrm{o}}\left(\mathrm{Na}^{+}, \mathrm{g}\right)+\right.} & \left.\Delta G_{\mathrm{aq}}^{\mathrm{o}}\left(\mathrm{X}^{-}, \mathrm{g}\right)\right] / \mathrm{kJ} \mathrm{mol}^{-1}=-193.86 V(\mathrm{NaX})^{-1 / 3} \\
& -186.34\left(N=4, R^{2}=0.999\right) \\
{\left[\Delta G_{\mathrm{aq}}^{\mathrm{o}}\left(\mathrm{K}^{+}, \mathrm{g}\right)+\right.} & \left.\Delta G_{\mathrm{aq}}^{\mathrm{o}}\left(\mathrm{X}^{-}, \mathrm{g}\right)\right] / \mathrm{kJ} \mathrm{mol}^{-1}=-263.35 V(\mathrm{KX})^{-1 / 3} \\
+ & 3.81\left(N=4, R^{2}=0.999\right) \\
{\left[\Delta G_{\mathrm{aq}}^{\mathrm{o}}\left(\mathrm{Rb}^{+}, \mathrm{g}\right)\right.} & \left.+\Delta G_{\mathrm{aq}}^{\mathrm{o}}\left(\mathrm{X}^{-}, \mathrm{g}\right)\right] / \mathrm{kJ} \mathrm{mol}^{-1}=-293.91 V(\mathrm{RbX})^{-1 / 3} \\
& +69.99\left(N=4, R^{2}=0.997\right)
\end{aligned}
$$

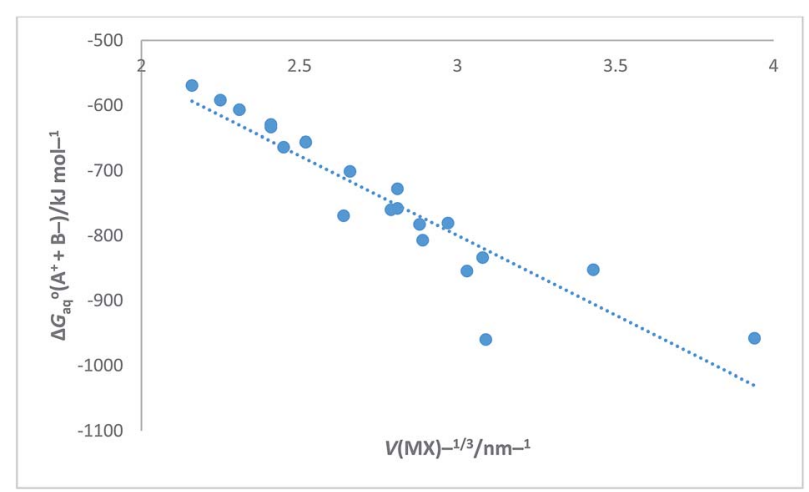

Fig. 9 Plot of Tissendier et al.'s data in Table 1 of ref. 52 for alkali halides (excluding $\mathrm{OH}^{-}$and $\mathrm{H}^{+}$data) of $\Delta G_{\mathrm{aq}}^{\circ}\left(\mathrm{A}^{+}+\mathrm{B}^{-}\right)=\left[\Delta G_{\mathrm{aq}}^{\circ}\left(\mathrm{M}^{+}, \mathrm{g}\right)+\right.$ $\left.\Delta G_{\text {aq }}^{\circ}\left(X^{-}, g\right)\right]=\left[\Delta G_{\text {hyd }}^{\circ}\left(M^{+}, g\right)+\Delta G_{\text {hyd }}^{\circ}\left(X^{-}, g\right)\right] / \mathrm{kJ} \mathrm{mol}^{-1}$ versus $V(M X)^{-1 / 3} /$ $\mathrm{nm}^{-1} . \Delta G_{\mathrm{aq}}^{\circ}\left(\mathrm{A}^{+}+\mathrm{B}^{-}\right) / \mathrm{kJ} \mathrm{mol}^{-1}=-245.38 \mathrm{~V}(\mathrm{MX})^{-1 / 3}-63.607(\mathrm{~N}=20$, $\left.R^{2}=0.8420\right)$ 
Table 9 Truhlar et al. ${ }^{51} \mathrm{Li}^{+}$ion cluster solvation free energy data taken from Table 4 of ref. 52

\begin{tabular}{|c|c|c|c|c|}
\hline $\begin{array}{l}n \text { value for } \\
\text { ion } \mathrm{Li}\left(\mathrm{H}_{2} \mathrm{O}\right)_{n}{ }^{+}\end{array}$ & $\begin{array}{l}\text { Hydrated ion volume } \\
V\left[\mathrm{M}\left(\mathrm{H}_{2} \mathrm{O}\right)_{n}{ }^{+}\right]=\left[V\left(\mathrm{Li}^{+}\right)\right. \\
\left.+n V\left(\mathrm{H}_{2} \mathrm{O}\right)\right]^{-1 / 3}=[0.0015 \\
+0.0245 n]^{-1 / 3} \mathrm{~nm}^{-1}\end{array}$ & $\begin{array}{l}\text { Experimental cluster-ion } \\
\text { solvation free energy, } \\
\Delta G_{\mathrm{cis}}^{\mathrm{O}} / \mathrm{kJ} \mathrm{mol}{ }^{-1}\end{array}$ & $\begin{array}{l}\text { Least squares fitted linear } \\
\text { prediction } \Delta G_{\text {cis }}^{\mathrm{o}} / \\
\mathrm{kJ} \mathrm{mol}^{-1} \text { eqn (34) }\end{array}$ & $\begin{array}{l}\text { Least squares polynomial } \\
\text { degree }=2 \text { prediction } \\
\Delta G_{\text {cis }}^{\mathrm{O}} / \mathrm{kJ} \mathrm{mol}^{-1} \text { eqn }(35)\end{array}$ \\
\hline 1 & 3.376 & -113.8 & -110.6 & -112.4 \\
\hline 2 & 2.705 & -192.9 & -201.5 & -199.3 \\
\hline 3 & 2.371 & -248.5 & -246.8 & -245.1 \\
\hline 4 & 2.158 & -279.9 & -275.6 & -275.1 \\
\hline 5 & 2.005 & -298.7 & -296.3 & -297.1 \\
\hline 6 & 1.888 & -309.2 & -312.2 & -314.1 \\
\hline 10 & 3.355 & & -352.3 & -357.6 \\
\hline
\end{tabular}

Here we see high correlation coefficients this time indicating an almost perfect linear fit and how the inverse cube root of the volume, $V^{-1 / 3}$ serves to correlate well with hydration derived data which was the aim of this paper.

If the hydrogen data in the free energy Table 1 in ref. 52 is plotted versus $V(\mathrm{HX})^{-1 / 3}$ we have the following correlations. Where $\mathrm{X}=\mathrm{F}, \mathrm{Cl}, \mathrm{Br}, \mathrm{I}$ :

$$
\begin{aligned}
{\left[\Delta G_{\mathrm{aq}}^{\mathrm{o}}\left(\mathrm{H}^{+}, \mathrm{g}\right)\right.} & \left.+\Delta G_{\mathrm{aq}}^{\mathrm{o}}\left(\mathrm{X}^{-}, \mathrm{g}\right)\right] / \mathrm{kJ} \mathrm{mol}^{-1}=-187.29 V(\mathrm{HX})^{-1 / 3} \\
& -892.85\left(N=4, R^{2}=0.999\right)
\end{aligned}
$$

and where hydroxides are also included:

$$
\begin{aligned}
{\left[\Delta G_{\mathrm{aq}}^{\mathrm{o}}\left(\mathrm{H}^{+}, \mathrm{g}\right)\right.} & \left.+\Delta G_{\mathrm{aq}}^{\mathrm{o}}\left(\mathrm{X}^{-}, \mathrm{g}\right)\right] / \mathrm{kJ} \mathrm{mol}^{-1}=-198.8 V(\mathrm{HX})^{-1 / 3} \\
& -863.84\left(N=5, R^{2}=0.991\right)
\end{aligned}
$$

again an extension of VBT procedures to hydration and other solution data is indicated.

The above correlations are made traversing across Tissandier's table (retaining a constant $\mathrm{M}^{+}$and $\mathrm{H}^{+}$). Tables $\mathrm{S} 13$ and $\mathrm{S} 14 \dagger$ give the results of making correlations down the table (retaining a constant $\mathrm{X}^{-}$) and are used to make a prediction of the results for the cesium salts.

Tissandier's included no data for cesium salts in his table and the various correlations give us a chance to compare the predictions for this data since we have results derived from state of the art data (in Table S9†). The results are:

Overall rectilinear fit (Fig. 9, plotted versus $V(\mathrm{MX})^{-1 / 3}$ ) has the following errors of prediction: $\mathrm{CsF}$ (3.3\%), $\mathrm{CsCl}(0.6 \%), \mathrm{CsBr}$ (3.3\%), CsI (4.7\%);

Rectilinear fits made down the table (Table S13, $\dagger$ plotted versus $\left.V(\mathrm{MX})^{-1 / 3}\right)$ give errors of prediction: CsF $(1.6 \%), \mathrm{CsCl}$ (5.7\%), CsBr (4.1\%), CsI (4.4\%);

Polynomial is fitted (Table $\mathrm{S} 14, \dagger$ plotted versus $V(\mathrm{MX})^{-1 / 3}$ ) to data from down the table errors are significantly reduced; $\mathrm{CsF}$ (0.4\%), CsCl (1.1\%), CsBr (1.7\%), CsI (2.0\%);

This leaves us to conclude that, as was found in Fig. S3, $\dagger$ plots made against $V(\mathrm{MX})^{-1 / 3}$ usually exhibit some curvature and thus a polynomial fit provides the preferred results.

\section{Truhlar's thermodynamic data for clusters}

Finally Table 4 in ref. 52 reproduced here as Table 9 provides data for cluster-ion solvation free energy (and enthalpy) and again in column 4 and 5 is seen that functions of $V\left[\mathrm{M}\left(\mathrm{H}_{2} \mathrm{O}\right)_{n}{ }^{+}\right]$ provide satisfactory representations in the form of smooth fits of the data and would support an extrapolation to give solvation free energies for $\mathrm{M}\left(\mathrm{H}_{2} \mathrm{O}\right)_{10}{ }^{+}$although probably not beyond. The fitted regression lines and polynomial (shown in Fig. S7 and S8† respectively) take the analytical forms:

$$
\begin{aligned}
\Delta G_{\mathrm{cis}}^{\mathrm{o}} / \mathrm{kJ} \mathrm{mol}^{-1} & =137.28\left[V\left(\mathrm{Li}\left(\mathrm{H}_{2} \mathrm{O}\right)_{n}{ }^{+}\right)\right]^{-1 / 3} \\
-571.38(N & \left.=6 ; R^{2}=0.9959\right)
\end{aligned}
$$

and

$\Delta G_{\mathrm{cis}}^{\mathrm{o}} / \mathrm{kJ} \mathrm{mol}^{-1}=-6.451\left[V\left(\mathrm{Li}\left(\mathrm{H}_{2} \mathrm{O}\right)_{n}{ }^{+}\right)\right]^{-2 / 3}$

$+171.15\left[V\left(\mathrm{Li}\left(\mathrm{H}_{2} \mathrm{O}\right)_{n}{ }^{+}\right)\right]^{-1 / 3}-613.95\left(N=6 ; R^{2}=0.9963\right)$

The hydrated ion volumes are calculated as:

$$
\left[V\left(\mathrm{Li}\left(\mathrm{H}_{2} \mathrm{O}\right)_{n}^{+}\right)\right]^{-1 / 3}=\left[V\left(\mathrm{Li}^{+}\right)+n V\left(\mathrm{H}_{2} \mathrm{O}\right)\right]^{-1 / 3}
$$

where $V\left(\mathrm{H}_{2} \mathrm{O}\right)$ is taken to be $0.0245 \mathrm{~nm}^{3}$. Table 9 gives the example of the hydrated $\mathrm{Li}^{+}$ion data. The fit to $V^{-1 / 3}$ gives a useful way to extrapolate the data from which is predicted for $\mathrm{M}\left(\mathrm{H}_{2} \mathrm{O}\right)_{10}{ }^{+} \Delta G_{\text {cis }}^{\mathrm{o}}=-352 \mathrm{~kJ} \mathrm{~mol}^{-1}$ from eqn (34) and $-358 \mathrm{~kJ}$ $\mathrm{mol}^{-1}$ from the polynomial fit of eqn (35) (see graph in Fig. S8 $\dagger$ ). Extrapolation by this means is preferable to using $\Delta G_{\text {cis }}^{\text {o }}$ plotted versus $n$ because the latter is in the form shown in Fig. $\mathrm{S} 9, \dagger$ the analytical form being:

$\Delta G_{\mathrm{cis}}^{\mathrm{o}} / \mathrm{kJ} \mathrm{mol}^{-1}=-112.6 \ln (n)-117.05\left(N=6 ; R^{2}=0.9924\right)$

For $n=10, \Delta G_{\text {cis }}^{\mathrm{o}}=-376 \mathrm{~kJ} \mathrm{~mol}^{-1}$ from eqn (37) assuming the fit to a logarithmic form is appropriate.

\section{Conclusion}

The conclusion is straightforward and short. It seems clear that the inverse cube root of the solid state volume, $V^{-1 / 3}$ usually correlates well with hydration thermodynamic parameters and can be used in a variety of ways, including extrapolations, interpolations as well as providing comparative data. As an extension of VBT the requirement to be very accurate is not usually necessary. 


\section{Acknowledgements}

The University of Warwick and of Basle are thanked by the authors for providing facilities. We thank our reviewers (especially \#2!) for his/her kind assistance in making sure our database was up to date. HDBJ is grateful for support from the Jenkins-Albright-Wilson fund for a trip to lecture at the University of Oviedo.

\section{References}

1 H. D. B. Jenkins, H. K. Roobottom, J. P. Passmore and L. Glasser, Inorg. Chem., 1999, 38, 3609.

2 H. D. B. Jenkins and L. Glasser, J. Am. Chem. Soc., 2000, 122, 632.

3 H. D. B. Jenkins, D. Tudela and L. Glasser, Inorg. Chem., 2002, 41, 2364.

4 H. D. B. Jenkins and D. Tudela, J. Chem. Educ., 2003, 80, 1482.

5 L. Glasser and H. D. B. Jenkins, Chem. Soc. Rev., 2005, 34, 866.

6 H. D. B. Jenkins, Sci. Prog., 2009, 92, 91.

7 L. Glasser and H. D. B. Jenkins, Phys. Chem. Chem. Phys., 2016, 18, 21226.

8 T. E. Mallouk, G. L. Rosenthal, G. Muller, R. Busasco and N. Bartlett, Inorg. Chem., 1984, 23, 3167.

9 T. S. Cameron, R. J. Deeth, I. Dionne, H. B. Du, H. D. B. Jenkins, I. Krossing, J. Passmore and H. K. Roobottom, Inorg. Chem., 2000, 39, 5614.

10 S. Brownridge, I. Krossing, J. Passmore, H. D. B. Jenkins and H. K. Roobottom, Coord. Chem. Rev., 2000, 197, 397.

11 H. D. B. Jenkins, H. K. Roobottom and J. Passmore, Inorg. Chem., 2003, 42, 2886.

12 H. D. B. Jenkins, I. Krossing, J. Passmore and I. Raabe, J. Fluorine Chem., 2004, 125, 1585.

13 T. S. Cameron, I. Dionne, H. D. B. Jenkins, S. Parsons, J. Passmore and H. K. Roobottom, Inorg. Chem., 2000, 39, 2042.

14 K. O. Christe and H. D. B. Jenkins, J. Am. Chem. Soc., 2003, $125,9457$.

15 K. O. Christe and H. D. B. Jenkins, J. Am. Chem. Soc., 2003, 125, 14210.

16 A. Decken, H. D. B. Jenkins, G. B. Nikiforov and J. Passmore, Dalton Trans., 2004, 2496.

17 D. A. Dixon, D. Feller, K. O. Christe, W. W. Wilson, A. Vij, V. Vij, H. D. B. Jenkins, R. M. Olson and M. S. Gordon, J. Am. Chem. Soc., 2004, 126, 834.

18 K. O. Christe, A. Vij, W. W. Wilson, V. Vij, D. A. Dixon, D. Feller and H. D. B. Jenkins, Chem. Br., 2003, 39, 17.

19 D. R. Rosseinsky, L. Glasser and H. D. B. Jenkins, J. Am. Chem. Soc., 2004, 126, 10472.

20 A. Decken, H. D. B. Jenkins, C. Knapp, G. B. Nikiforov, J. Passmore and J. M. Rautiainen, Angew. Chem., Int. Ed., 2005, 44, 7958.

21 H. S. Elliott, J. F. Lehmann, H. P. A. Mercier, H. D. B. Jenkins and G. J. Schrobilgen, Inorg. Chem., 2010, 49, 8504.
22 K. K. Bhasin, M. J. Crawford, H. D. B. Jenkins and T. M. Klapötke, Z. Anorg. Allg. Chem., 2006, 632, 897.

23 S. Brownridge, L. Calhoun, H. D. B. Jenkins, R. S. Laitinen, M. P. Murchie, J. Passmore, J. Pietikainen, J. M. Rautiainen, J. C. P. Sanders, G. J. Schrobilgen, R. J. Suontamo, H. M. Tuononen, J. U. Valkonen and C. M. Wong, Inorg. Chem., 2009, 48, 1938.

24 H. D. B. Jenkins, L. Glasser and J. F. Liebman, J. Chem. Eng. Data, 2010, 55, 4369.

25 L. Glasser and F. Jones, Inorg. Chem., 2009, 48, 1661.

26 K. O. Christe, R. Haiges, J. A. Boatz, H. D. B. Jenkins, E. B. Garner and D. A. Dixon, Inorg. Chem., 2011, 50, 3752.

27 A. Vegas, J. F. Liebman and H. D. B. Jenkins, Acta Crystallogr., Sect. B: Struct. Sci., 2012, 68, 511.

28 H. D. B. Jenkins, D. Holland and A. Vegas, Thermochem. Acta., 2016, 633, 24.

29 D. W. M. Hofmann, Acta Crystallogr., Sect. B: Struct. Sci., 2002, 57, 489.

30 H. D. B. Jenkins and L. Glasser, J. Am. Chem. Soc., 2004, 126, 15809.

31 L. Glasser and H. D. B. Jenkins, Inorg. Chem., 2007, 46, 9768. 32 H. D. B. Jenkins and J. F. Liebman, J. Chem. Eng. Data, 2009, 54, 351.

33 H. D. B. Jenkins and L. Glasser, J. Chem. Eng. Data, 2010, 55, 4231.

34 H. D. B. Jenkins, L. Glasser and J. F. Liebman, J. Chem. Eng. Data, 2010, 55, 4369.

35 H. D. B. Jenkins and C. E. Housecraft, J. Chem. Thermodyn., 2017, submitted for publication.

36 L. Glasser, H. D. B. Jenkins and T. M. Klapotke, Z. Anorg. Allg. Chem., 2014, 640, 1297.

37 A. Vegas, J. F. Liebman and H. D. B. Jenkins, Acta Crystallogr., Sect. B: Struct. Sci., 2012, 68, 511.

38 A. Vegas and H. D. B. Jenkins, Acta Crystallogr., Sect. B: Struct. Sci., Cryst. Eng. Mater., 2017, 73, 94.

39 S. V. Makarov, S. Sal'nikov and A. S. Pogorelova, Russ. J. Inorg. Chem., 2010, 55, 301.

40 S. V. Makarov, D. S. Sal'nikov and A. S. Pogorelova, Zh. Neorg. Khim., 2010, 55, 309.

41 S. A. Svarovsky, R. H. Simoyi and S. V. Makarov, J. Chem. Soc., Dalton Trans., 2000, 511.

42 F. A. LeBlanc, A. Decken, T. S. Cameron, J. Passmore, J. M. Rautiainen and T. K. Whidden, Inorg. Chem., 2017, 56, 974.

43 K. K. Bhasin, M. J. Crawford, H. D. B. Jenkins and T. M. Klapotke, Z. Anorg. Allg. Chem., 2016, 632, 897.

44 D. Srinivas, V. Ghule, K. Muralidharan and H. D. B. Jenkins, Chem.-Asian. J., 2013, 8, 1023.

45 P. Bruna, A. Decken, S. Greer, F. Grein, H. D. B. Jenkins, B. Mueller, J. Passmore, T. A. P. Paulose, J. M. Rautiainen and S. Richardson, Inorg. Chem., 2013, 52, 13651.

46 E. Zintl, Angew. Chem., 1939, 52, 1.

47 W. Klemm, Proc. R. Soc. London, Ser. A, 1958, 329.

48 H. D. B. Jenkins and A. Vegas, Acta Crystallogr., Sect. B, 2017, eb5061.

49 H. D. B. Jenkins and A. Vegas, Acta Crystallogr., Sect. B: Struct. Sci., Cryst. Eng. Mater., 2017, eb5062. 
50 A. Vegas, New Models in Inorganic Structures - from elements to compounds, International Union of Crystallography/ Oxford University Press, 2017, MS in preparation.

51 C. P. Kelly, C. J. Cramer and D. G. Truhlar, J. Phys. Chem. B, 2006, 110, 16066.

52 M. D. Tissendier, K. A. Cowen, W. Y. Feng, E. Grundlach, M. H. Cohen, A. D. Earhart, J. V. Coe and T. R. Tuttle Jr, J. Phys. Chem. A, 1998, 102, 7787.

53 J. V. Coe, Chem. Phys. Lett., 1994, 229, 161.

54 http://kinetics.nist.gov/janaf/.

55 M. Born, Zeitschrift für Physik, 1920, 1, 45.

56 Y. Marcus, Ion Properties, Marcel Dekker, New York, 1997.

57 P. Vieillard, Acta Crystallogr., Sect. B: Struct. Sci., 1987, 43, 513.

58 V. M. Goldschmidt, Geochemische Verteilungsgesetze der Elemente, Skrifter Norske Videnskapp-Akad, Oslo, I, Mat, -Naturv. Kl, 1926.

59 L. Pauling, Nature of the Chemical Bond, Oxford University Press, 3rd edn, 1960.

60 E. J. King, J. Phys. Chem., 1970, 74, 4590.

61 D. W. M. Hofmann, Acta Crystallogr., Sect. B: Struct. Sci., 2002, 57, 489.

62 D. M. Camaioni and C. A. Schwerdtfeger, J. Phys. Chem. A, 2005, 109, 10795.
63 D. R. Lide, Handbook of Chemistry \& Physics, CRC Press, Boca Raton, 80th edn, 1999-2000, pp. 5-85.

64 D. D. Wagman, W. H. Evans, V. B. Parker, R. H. Schumm, I. Halow, S. M. Bailey, K. L. Churney and R. L. Nutall, NBS Tables of Chemical Thermodynamic Properties, 1982, J. Phys. Chem. Ref. Data, vol. 11, Supplement 2.

65 J. F. Zemaitis, D. M. Clark, M. Rafal and N. C. Scrivner, Handbook of Aqueous Electrolyte Thermodynamics, American Institute of Chemical Engineers, New York, 1986.

66 C. P. Kelly, C. J. Cramer and D. G. Truhlar, J. Chem. Theory Comput., 2005, 1, 1133.

67 J. R. Pliego Jr and J. M. Riveros, Chem. Phys. Lett., 2000, 332, 597.

68 G. J. Tawa, I. A. Topol, S. K. Burt, R. A. Cladwell and A. A. Rashin, J. Chem. Phys., 1998, 109, 4852.

69 J. R. Pliego Jr and J. M. Riveros, J. Chem. Phys., 2000, 112, 4045.

70 J. R. Pliego Jr and J. M. Riveros, J. Phys. Chem. B, 2000, 104, 5155.

71 J. R. Pliego Jr and J. M. Riveros, Phys. Chem. Chem. Phys., 2002, 4, 1622.

72 O. L. Davies and P. L. Goldsmith, Statistical Methods in Research and Production, Oliver \& Boyd, 4th edn, 1972.

73 http://Surfstat.anu.edu.au/serfstat-home/tables/t.php. 